\title{
High-resolution modelling of interactions between soil moisture and convective development in a mountain enclosed Tibetan Basin
}

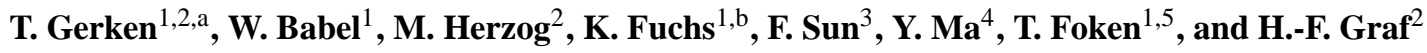 \\ ${ }^{1}$ Department of Micrometeorology, University of Bayreuth, Bayreuth, Germany \\ ${ }^{2}$ Centre for Atmospheric Science, Department of Geography, University of Cambridge, Cambridge, UK \\ ${ }^{3}$ Cold and Arid Regions Environmental and Engineering Research Institute, Chinese Academy of Sciences, Lanzhou, China \\ ${ }^{4}$ Key Laboratory of Tibetan Environment Changes and Land Surface Processes, Institute of Tibetan Plateau Research, \\ Chinese Academy of Sciences, CAS Center for Excellence in Tibetan Plateau Earth Sciences, Beijing, China \\ ${ }^{5}$ Member of Bayreuth Center of Ecology and Environment Research (BayCEER), Bayreuth, Germany \\ anow at: Department of Meteorology, The Pennsylvania State University, University Park, PA, USA \\ b now at: Institute of Agricultural Science, ETH Zürich, Zurich, Switzerland \\ Correspondence to: T. Gerken (tobias.gerken@uni-bayreuth.de)
}

Received: 27 March 2015 - Published in Hydrol. Earth Syst. Sci. Discuss.: 4 May 2015

Revised: 20 August 2015 - Accepted: 15 September 2015 - Published: 29 September 2015

\begin{abstract}
The Tibetan Plateau plays a significant role in atmospheric circulation and the Asian monsoon system. Turbulent surface fluxes and the evolution of boundary-layer clouds to deep and moist convection provide a feedback system that modifies the plateau's surface energy balance on scales that are currently unresolved in mesoscale models. This work analyses the land surface's role and specifically the influence of soil moisture on the triggering of convection at a cross section of the Nam Co Lake basin, $150 \mathrm{~km}$ north of Lhasa using a cloud-resolving atmospheric model with a fully coupled surface. The modelled turbulent fluxes and development of convection compare reasonably well with the observed weather. The simulations span Bowen ratios of 0.5 to 2.5. It is found that convective development is the strongest at intermediate soil moisture. Dry cases with soils close to the permanent wilting point are moisture limited in convective development, while convection in wet soil moisture cases is limited by cloud cover reducing incoming solar radiation and sensible heat fluxes, which has a strong impact on the surface energy balance. This study also shows that local development of convection is an important mechanism for the upward transport of water vapour, which originates from the lake basin that can then be transported to dryer regions of the plateau. Both processes demonstrate the importance of soil moisture and surface-atmosphere interactions on the energy and hydrological cycles of the Tibetan Plateau.
\end{abstract}

\section{Introduction}

The Tibetan Plateau has an average elevation of more than $4500 \mathrm{~m}$ and is the world's largest mountain highland. Land use/land cover change, such as permafrost (Cheng and $\mathrm{Wu}$, 2007) and grassland degradation or deforestation (Cui and Graf, 2009; Cui et al., 2006), but also effects on the carbon and hydrological cycles (Babel et al., 2014), are associated with overuse of resources and climate change. They also affect atmospheric circulation and hydrological resources of the Tibetan Plateau, especially the cryosphere (i.e. Yao et al., 2007; Ni, 2011; Kang et al., 2010; Yang et al., 2011, 2014). Effects on the hydrological cycle are likely enhanced due to changes in phenology and length of the growing season (Shen et al., 2014; Che et al., 2014; Zhang et al., 2014). According to Immerzeel et al. (2010) more than 1.4 billion people in Southeast Asia live in the catchments of rivers originating on the Tibetan Plateau. It is therefore important to gain a better understanding of the hydrological processes in the region.

Surface-atmosphere interactions through the exchange of momentum, turbulent energy and water vapour play an important role in the development of convection and thus influence the energy balance of the surface and local precipitation. On the plateau scale, the surface energy balance impacts the plateau's role as an elevated heat source (i.e. Flohn, 1952; 
Gao et al., 1981; Yanai et al., 1992). This heating is probably not the main driver of the Indian monsoon system (Molnar et al., 2010; Boos and Kuang, 2010), but acts to modify it and influences regional atmospheric circulation as well as eastern Asian precipitation (i.e. Liang and Wang, 1998; Zhou et al., 2004). While conventional atmospheric circulation models do not have a high enough resolution to resolve the relevant hydrological processes on the local scale, cloudresolving models with a fully coupled surface model, as introduced by Patton et al. (2005), present a valuable tool for the systematic investigation of surface-atmosphere interactions, convective development and locally generated precipitation.

The triggering of deep convection over topography is a major source of precipitation in mountainous environments (e.g. Banta and Barker Schaaf, 1987; Gochis et al., 2004). The summer monsoon season is associated with an increase of the total precipitable water in the atmosphere from approx. 5 to $>15 \mathrm{~mm}$ and a destabilisation of the atmospheric profile (Taniguchi and Koike, 2008). A diurnal cycle in cloud development leading to the triggering of local convection before noon is commonly observed on the Tibetan Plateau and is organised by thermal valley circulations (i.e. Ueno, 1998; Ueno et al., 2009; Yatagai, 2001; Kuwagata et al., 2001; Kurosaki and Kimura, 2002). This organisation of local circulation leads to daytime precipitation over mountain ridges and to night-time precipitation from convergence in the basin centre (Ueno et al., 2009). Modelling studies (Kuwagata et al., 2001) and remote sensing (Yatagai, 2001) have determined valley scales of $160-240 \mathrm{~km}$ to be most effective for these processes. Yang et al. (2004) have also investigated thermal circulations on the Tibetan Plateau and found secondary triggering of convection within Tibetan valleys as a result of cold-pool fronts caused by convective events that were triggered over the mountains. Similar effects were simulated for Nam Co Lake as the result of a combined lake breeze-thermal mountain circulation (Gerken et al., 2014). Uyeda et al. (2001) measured maximum cloud top heights of $17 \mathrm{~km}$ a.s.l. in the Nagqu Basin occurring between 12:00 and 15:00 LT. Yamada and Uyeda (2006) found different structures of convection and precipitation on the Tibetan Plateau, which were associated with dry and moist surfaces. Dry surfaces during the pre-monsoon led to a high cloud base and increased re-evaporation of precipitation, while moist surfaces during the monsoon yielded lower cloud bases and higher rates of deposited precipitation. A modelling investigation (Yamada, 2008) confirmed this process and showed stronger convective motion for the dry case. Hence, complex interaction of local and larger scale circulation with local environmental conditions are essential for the evolution of clouds and the hydrological cycle on the Tibetan Plateau.

The influence of the monsoon declines to the North on the Tibetan Plateau (Tian et al., 2001, 2003, 2007). At the same time local moisture recycling on the central plateau becomes essential keeping the regional water cycle active (Kurita and
Yamada, 2008). Their research highlights the importance of the boundary layer as a major source of the precipitated water during night-time and of locally generated convection. Convection and precipitation at Nam Co Lake are both influenced by the lake's water body (Li et al., 2009) and the complex topography (Maussion et al., 2011, 2014).

We previously investigated surface-atmosphere interactions, the development of mesoscale circulations and the evolution of convection in the Nam Co Lake basin. In Gerken et al. (2014), we applied a surface model (Gerken et al., 2012), coupled to the cloud-resolving ATHAM (Active Tracer High-resolution Atmospheric Model - Oberhuber et al., 1998; Herzog et al., 1998) and analysed convective triggering at Nam Co Lake. It was shown that the model can reproduce the most important atmospheric dynamics of the Nam Co Basin. Subsequently, the impact of different atmospheric profiles on convection and precipitation was investigated (Gerken et al., 2013a). These studies highlighted the importance of surface-atmosphere interactions in the generation of precipitation and convection.

Observed Bowen ratios at Nam Co station vary from 3 to 0.5 , with maximum latent heat fluxes exceeding $400 \mathrm{~W} \mathrm{~m}^{-2}$ during wet conditions (Gerken et al., 2012). As a consequence Nam Co Lake can be classified as a semi-arid transitional region with strong soil moisture-climate coupling (Seneviratne et al., 2010). While the existence of feedbacks between land-surface moisture, rainfall and convective development is well known, there is disagreement on the dominating processes and the sign of the resulting feedback (Barthlott et al., 2011). Following the mechanism by Pal and Eltahir (2001), increased soil moisture increases the boundary layer's total convective available energy and lowers the lifting condensation level; both increase moist convection. At the same time, decreased solar radiation input due to larger cloud cover can reduce the available energy and thus convective development (Seneviratne et al., 2010; Pal and Eltahir, 2001; Pan et al., 1996). While soil moistureatmosphere interactions occur on many different spatial and temporal scales, interactions on the seasonal scale are well documented (e.g. Fischer et al., 2007). Taylor et al. (2012) showed that the likelihood of convective precipitation over wet soils was increased. Interactions on shorter timescales are less well understood. Clark et al. (2004) have demonstrated that moisture variability on the $10 \mathrm{~km}$ scale can induce regional circulations that enhance convection. Additional evidence for the influence of soil-moisture-induced mesoscale circulations on convective development was found in observational (Taylor et al., 2007) and modelling studies (e.g. Cheng and Cotton, 2004; Garcia-Carreras et al., 2010). Due to the localised convection triggering on the Tibetan Plateau, such processes might also play a role for precipitation at Nam Co Lake.

Compared to studies over flat terrain, much less is known about soil moisture-convection feedbacks above complex topography. Hohenegger et al. (2009) found a dependence on 
the model resolution in the Alpine region. Convection permitting resolutions led to predominantly negative feedbacks, caused by the presence of a stable layer above the boundary layer, while lower resolutions with parameterized convection showed positive feedbacks. Similarly, Barthlott et al. (2011) and Hauck et al. (2011) found considerable feedbacks between soil moisture and precipitation, but with a variable sign of the feedback. They identified convective inhibition as a major cause.

It is, therefore, key to understand soil moisture precipitation dynamics and its feedbacks at Nam Co Lake and similar basins to gain a better understanding of the hydrological cycle on the Tibetan Plateau scale. This work investigates the role of the interactions between the lake, the surrounding basin with complex topography and the atmosphere in the development of boundary-layer clouds and their evolution into deep moist convection. We analyse (1) the sensitivity of convective development to surface moisture, (2) the modification of the surface energy balance through feedbacks between surface fluxes, specifically evapotranspiration, and cloud development and (3) the implications for locally triggered, convective precipitation at Nam Co Lake.

\section{Material and methods}

\subsection{Site description}

Nam Co Lake, approx. elevation $4730 \mathrm{~m}$ a.s.1., is located circa $150 \mathrm{~km}$ north of Lhasa and just to the north of the Nyenchen Thangla mountain chain, which has maximum peak heights of more than $7000 \mathrm{~m}$. The average elevation of the Nam Co Basin is $5230 \mathrm{~m}$ (Liu et al., 2010). Between 6 July and 6 August 2012 scientists from the University of Bayreuth conducted a field experiment at Nam Co Lake in cooperation with the Institute of Tibetan Plateau Research, Chinese Academy of Sciences. The Nam Co Lake Monitoring and Research Station for Multisphere Interactions (Ma et al., 2009) is located at $30^{\circ} 46.44^{\prime} \mathrm{N}, 90^{\circ} 57.72^{\prime} \mathrm{E}$. It is situated at a distance of $300 \mathrm{~m}$ from a small lake, which is divided from Nam Co Lake to the north-west through a $500 \mathrm{~m}$ wide land bridge. The experiment is documented in Gerken et al. (2013b). Radiosondes were released on 8 days between 17 and 29 July for 00:00, 06:00 and 12:00 UTC. Eddycovariance flux measurements were performed with a CSAT3 sonic anemometer and $\mathrm{KH} 2 \mathrm{O}$-krypton hygrometer (both Campbell Scientific). The $\mathrm{KH} 2 \mathrm{O}$ was calibrated on site in accordance with Foken and Falke (2012). Standard atmospheric and soil temperature as well as moisture measurements were also carried out.

As described in Gerken et al. (2014), the TK2/3 software package (Mauder and Foken, 2004, 2011) was used to post-process the high-frequency measurements. All flux corrections and post-processing steps recommended in Foken et al. (2012) and Rebmann et al. (2012) were applied to
Table 1. Description of the soil and surface parameters at Nam Co station $\left(30^{\circ} 46.44^{\prime} \mathrm{N}, 90^{\circ} 57.72^{\prime} \mathrm{E}\right)$ and which are also used for the simulations. Leaf area index (LAI) and vegetation height were estimated for July 2012 (Biermann et al., 2009). The table is modified from Gerken et al. (2013a).

\begin{tabular}{ll}
\hline Parameter & \\
\hline Texture & sandy \\
Porosity & 0.39 \\
Field capacity & 0.05 \\
Wilting point & 0.02 \\
Heat capacity $\left(c_{p}\right)\left[\mathrm{J} \mathrm{m}^{-3} \mathrm{~K}^{-1}\right]$ & $2.2 \times 10^{6}$ \\
Thermal & 0.20 \\
Conductivity $\left[\mathrm{W} \mathrm{m} \mathrm{m}^{-2} \mathrm{~K}^{-1}\right]$ & \\
Surface albedo $(\alpha)$ & 0.2 \\
Surface emissivity $(\epsilon)$ & 0.97 \\
Vegetated fraction & 0.6 \\
LAI [m $\left.{ }^{2} \mathrm{~m}^{-2}\right]$ & 0.6 \\
Vegetation height $[\mathrm{m}]$ & 0.07 \\
\hline
\end{tabular}

the flux data. Unlike surface models, the energy balance of eddy-covariance measurements is inherently unclosed (i.e. Foken, 2008; Foken et al., 2011). The presence of stationary, secondary circulations leads to a missing flux fraction of approx. $30 \%$ at Nam Co Lake. Therefore, before comparing measured and modelled fluxes, it is necessary to correct eddy-covariances fluxes according to the Bowen ratio (Twine et al., 2000). Additional information about flux dynamics at Nam Co Lake can be found in Biermann et al. (2014). Vaisala RS92-SGP radiosondes on Totex-TA600 balloons were launched from a portable Vaisala sounding system with a mobile GPS antenna and signals were processed with the SPS-220 unit and DigiCora III MW21 software v3.2.1.

This work uses mean local time throughout, which is close to UTC $+6 \mathrm{~h}$ or $2 \mathrm{~h}$ before Beijing Standard Time. On 17 July sunrise, solar noon and sunset were determined with the National Oceanic and Atmospheric Administration Sunrise/Sunset Calculator as 23:05, 06:02 and 13:00 UTC.

The soil was characterized in 2009 (Biermann et al., 2009) and the vegetation classification was reassessed in 2012 (Gerken et al., 2014, see Table 1). Except for some wetlands close to the lake, the basin and surroundings of the station are sparsely vegetated and classed as alpine meadow and steppe (Mügler et al., 2010). Figure 1 shows the Nam Co Lake basin and includes the flight path of the radiosonde launched for 17 July, 06:00 LT (00:00 UTC). The soil is estimated to have little water retention capacity and a low permanent wilting point (PWP) at $2 \%$. While the field capacity used for the modelling of $5 \%$ is very small, it is not unreasonably low for a sandy soil and produced good agreement of measured and simulated fluxes in Gerken et al. (2012). 


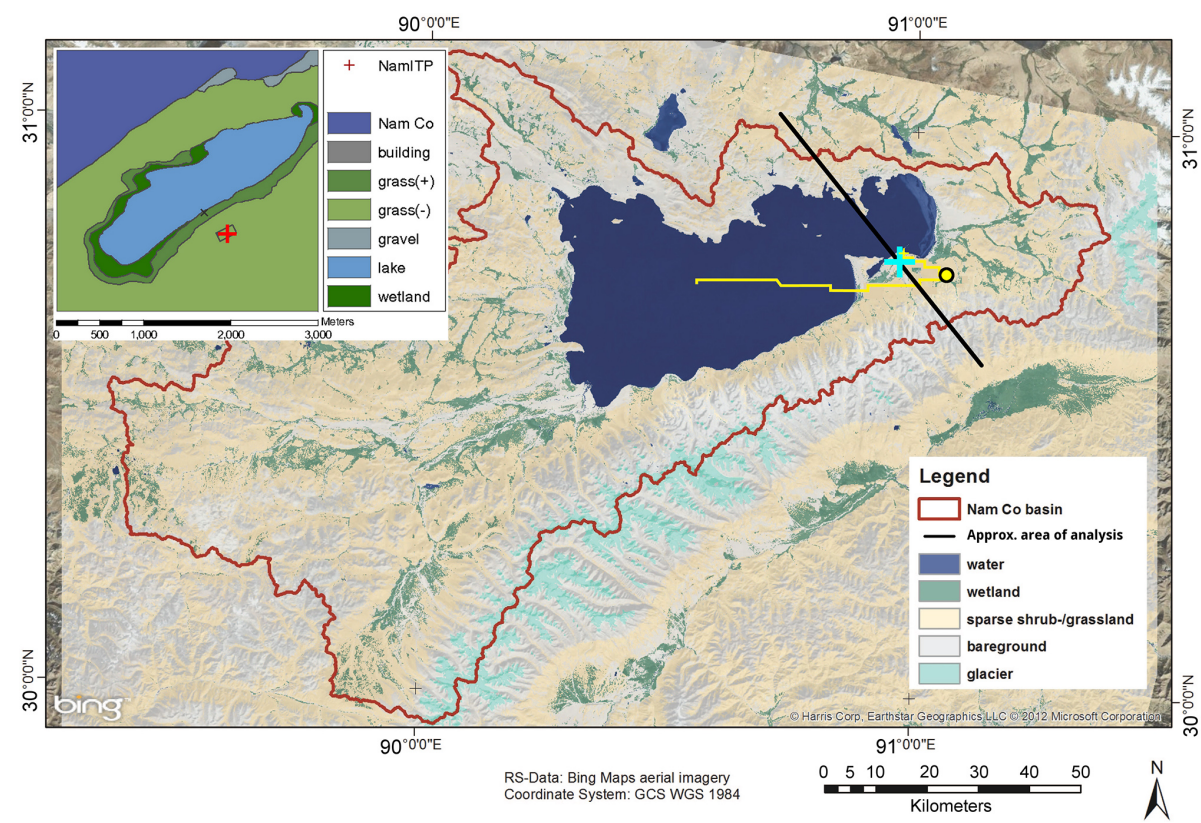

Figure 1. Land use map of Nam Co Lake created from Landsat data. The yellow line shows the path of radiosonde ascent on 17 July 2012 , 00:00 UTC. The yellow circle indicates the location at which the radiosonde reaches $10 \mathrm{~km}$ a.g.1. and the cold-point height. The cyan cross indicates the location of Nam Co station. The inset, reproduced from Gerken et al. (2012), shows the area near the small lake and the location of Nam Co Station (NamITP). ${ }^{\circledR}$ 2012, The Microsoft Corporation, ${ }^{\circ}$ Harris Corp, Earthstar Geographics LLC.

\subsection{Model description}

The non-hydrostatic, cloud-resolving ATHAM model (Oberhuber et al., 1998; Herzog et al., 1998, 2003), used in this study has originally been developed to simulate volcanic eruption plumes (Graf et al., 1999). Subsequently, it was applied to biomass-burning plumes (e.g. Trentmann et al., 2006) and atmospheric applications (Guo et al., 2004). The model uses a $z$ vertical coordinate, and can be run both in 2-D and 3-D mode. Tracers, including all hydrometeors, are active. This means that the density of the gas-particle mixture and heat capacity of the fluid are influenced by the local concentration of all tracers (Oberhuber et al., 1998).

The simulations in this work include the following physical processes, and are similar to the work in Gerken et al. (2013a): shortwave radiation (Langmann et al., 1998), longwave radiation (Mlawer et al., 1997), and bulk microphysics (Herzog et al., 1998). Turbulence closure is of the order of 1.5 and predicts both turbulent length scale and turbulent kinetic energy (horizontal and vertical) (Herzog et al., 2003). The modified Hybrid (v6) land-surface model (Friend et al., 1997; Friend and Kiang, 2005; Gerken et al., 2012) and the Coupled Ocean-Atmosphere Response Experiment (COARE) algorithm v2 (Fairall et al., 1996a, b) water surface scheme compute turbulent energy fluxes above land and water. Nam Co Lake has a mean depth of $>50 \mathrm{~m}$ (Wang et al., 2009). The surface model and the coupled system were shown to perform well for this site (Gerken et al., 2012, 2013a, 2014) and the reader is referred to these publications for a more extensive model description.

\subsection{Model set-up and cases}

Due to the almost parallel orientation of Nam Co Lake and the Nyenchen Thangla mountains, it is possible to simulate the system's most important dynamical features such as the diurnal cycle of turbulent fluxes, the formation of a lake breeze and the interaction between locally generated clouds and the complex topography using a 2-D approach (Gerken et al., 2013a, 2014). Our model domain cuts across the lake, the Nam Co station, as location of our measurements, and through the Nyenchen Thangla mountain chain, which is of relatively low height at this location compared to the glaciated peaks in the western range. The maximum elevation difference between the lake level and the mountain chain is approx. $800 \mathrm{~m}$. As the 2-D modelling set-up does not permit flow around the mountain chain, we expect to overestimate the influence of topography.

The 2-D domain used in this work has the same configuration as in Gerken et al. (2013a) with a total extent of $153.6 \mathrm{~km}$ divided into 770 grid points with a horizontal resolution of $200 \mathrm{~m}$. There are 175 vertical layers with the first 50 layers at $50 \mathrm{~m}$ resolution and the remaining layers stretch to a resolution of $200 \mathrm{~m}$, which is kept constant for the uppermost 50 model layers. The vertical domain extends to $17.5 \mathrm{~km}$ a.g.l. For the topography we use the $90 \mathrm{~m}$ resolution ASTER digital elevation model. While a $2 \mathrm{~km}$ mov- 


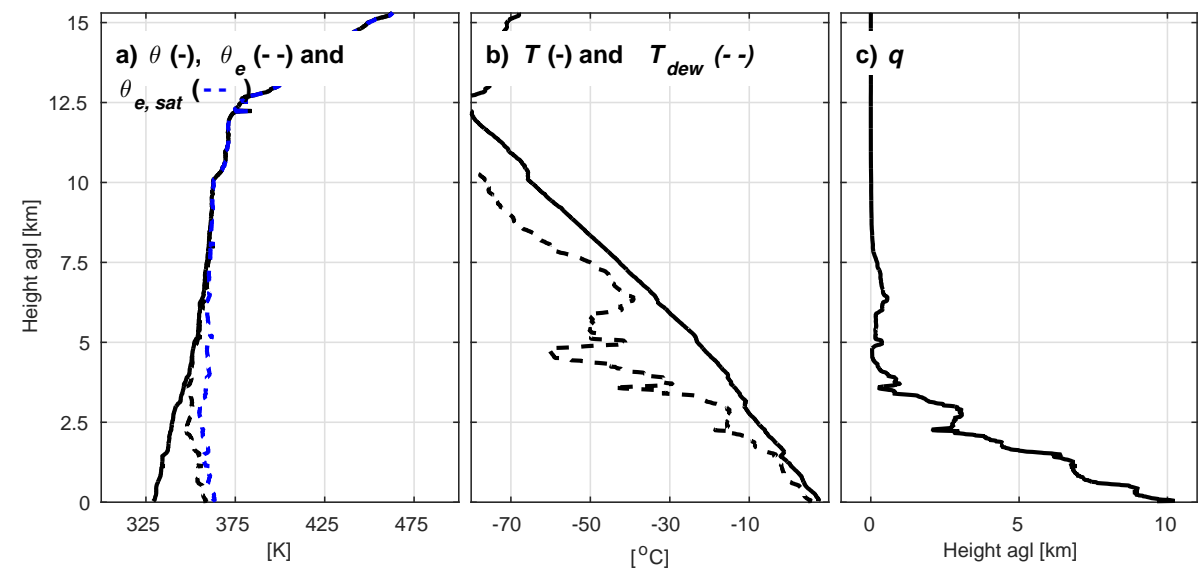

Figure 2. Initial profile for Nam Co Lake 17 July 2012 06:00 LT used in the model simulations as measured by radiosonde. (a) Potential ( $\theta$ ), equivalent potential temperature $\left(\theta_{\mathrm{e}}\right)$, and saturated equivalent potential temperature $\left(\theta_{\mathrm{e}, \text { sat }}\right)$; (b) temperature $(T)$ and dew-point temperature $\left(T_{\text {dew }}\right)$ and (c) mixing ratio $(q)$.

ing window was used to smooth the topography within the basin, convective development has a negligible sensitivity to the window size as shown in the supplement to Gerken et al. (2013a). Outside the Nam Co Basin the topography is set to the same elevation as the lake. Surface energy fluxes are gradually reduced to zero in the vicinity of the horizontal boundary, as we are interested in the behaviour of the mountain-lake system enclosed by mountains and hills. In contrast to cyclic lateral boundary conditions for momentum, hydrometeor tracers and water vapour concentrations exceeding the initialised profile are removed, without introducing a density perturbation. The 2-D simulations are integrated from 04:00 to 20:00 LT. The model time step is $2.5 \mathrm{~s}$. To assess the suitability of the 2-D simulations, we compare the convective development in 2-D with a 3-D simulation of the cross section that allows for the triggering of convection in three dimensions. The 3-D simulation spans the same domain in the principal horizontal and vertical dimension, and is integrated over the first $12 \mathrm{~h}$. While the vertical resolution is identical to the 2-D simulations, the horizontal domain resolves the central $80 \mathrm{~km}$ and thus the lake basin and topographic elements at $200 \mathrm{~m}$ and then applies a grid stretching to span the total domain with a total of 490 grid points. The second horizontal dimensions span $10 \mathrm{~km}$ with $200 \mathrm{~m}$ resolution and uniform topography in the $y$ direction. The lateral boundary in this dimension is fully cyclic.

The 17 July 2012 was selected as the basis for the investigations presented in this work as this day was free of large-scale synoptic effects, which are not included in the model, and showed a characteristic evolution from clear sky with few boundary-layer clouds to locally generated " $\mathrm{Cu}$ mulonimbus" activity. Gerken et al. (2013a) showed that the model realistically reproduced the observed weather and the evolution of the vertical profiles for temperature and moisture. Figure 2 displays the temperature and moisture profiles derived from the 00:00 UTC radiosounding of 17 July. The initial relative humidity $(\mathrm{RH})$ of the atmospheric profile is reduced to a maximum of $90 \%$. This is reasonable as there was no closed cloud cover at the time of the sounding so that cloud passages of a radiosonde would lead to an overestimation of relative humidities at the respective level. As the focus of this work is the investigation of the impacts of varying soil moisture, the initial geostrophic wind is set to $3 \mathrm{~m} \mathrm{~s}^{-1}$ throughout the model domain, which exhibited the most realistic convection in Gerken et al. (2014). This also avoids wind shear to which 2-D simulations are very sensitive (i.e. Kirshbaum and Durran, 2004). The model was initialised with 6.8 and $2.6^{\circ} \mathrm{C}$ as first and second layer mean temperatures $\overline{T_{1}}$ and $\overline{T_{2}}$, which corresponds to an initial surface temperature $\left(T_{0}\right)$ of $4.5^{\circ} \mathrm{C}$. For the complete description of the Hybrid surface model initialisation the reader is referred to Gerken et al. (2012). Soil moisture in the surface model is initialised as a fraction of field capacity (FC), which is the amount of water a soil can hold against gravity. In order to investigate the influence of soil moisture on convective development, we set the initial soil moisture of the simulations to $2.0,1.5,1.0$, $0.75,0.5$ and $0.4 \times$ FC. These cases are subsequently referred to by their initial soil moisture (e.g. " $1.0 \times$ FC").

While the $2.0 \times \mathrm{FC}$ case corresponds to a realistic surface initialisation for 17 July, we leave soil temperatures and thus soil heat contents unmodified and reduce soil moisture gradually to the permanent wilting point $(\mathrm{PWP}=0.4 \times \mathrm{FC})$. The lake surface temperature is initialised with $10^{\circ} \mathrm{C}$, which is reported by Haginoya et al. (2009) as Nam Co Lake's mean surface temperature in July and August for 2006-2008. 

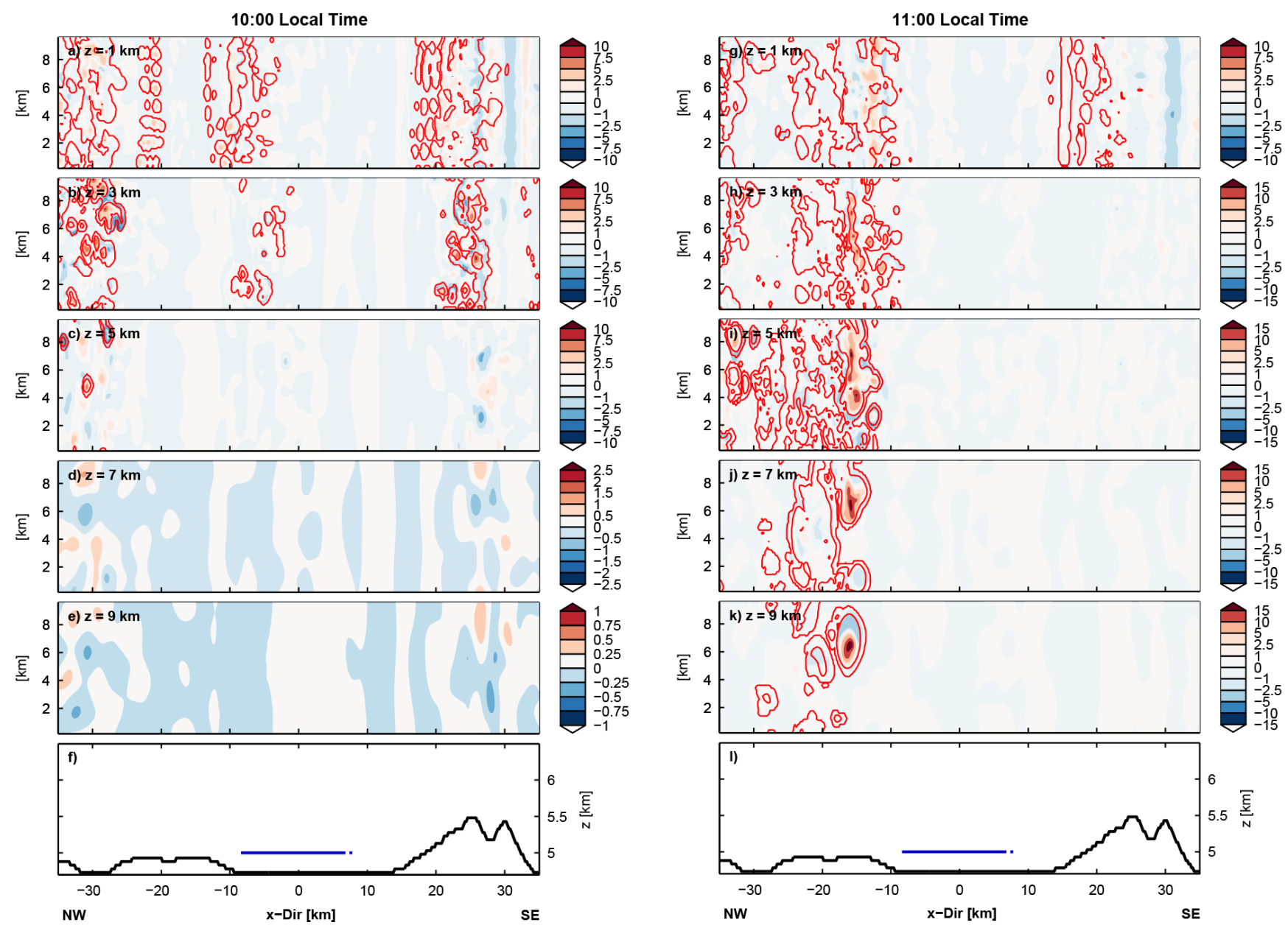

Figure 3. Development of convection in the 3-D simulation of case $2.0 \times$ FC at 10:00 LT for heights 1, 3, 5, 7 and $9 \mathrm{~km} \mathrm{a.g.1.} \mathrm{(a-e);} \mathrm{at}$ 11:00 LT (g-k). The filled contours indicate vertical velocities $\left(w,\left[\mathrm{~m} \mathrm{~s}^{-1}\right]\right)$ and the red contour lines show the location of clouds; (f, l) display the topography of the model domain. The location of the lake is indicated by the blue line.

\section{Results and discussion}

\subsection{Comparison of 2-D vs. 3-D}

While 2-D simulations of deep convective development are frequently used to investigate the triggering of convection (i.e. Wu et al., 2009; Kirshbaum, 2011; Garcia-Carreras et al., 2011), they may overestimate convection due to the lack of entrainment in their convective plumes (e.g. Petch et al., 2008). As a consequence, we start the analysis by comparing the convective development for case $2.0 \times \mathrm{FC}$ between the 2-D and 3-D simulations. As in Gerken et al. (2013a), we consider grid elements with liquid water contents (both water and ice) of $q_{t}>10^{-3} \mathrm{~g} \mathrm{~kg}^{-1}$ as clouds.

Figure 3 shows the development of vertical velocities and cloud cover at several heights for 10:00 and 11:00 LT for the case $2.0 \times$ FC in the 3-D set-up. During this time boundarylayer clouds that form near the mountains and hills develop into a convective plume that reaches $9 \mathrm{~km}$ a.g.l. at 10:30 LT (not shown) and then develops further. Overall, this results in maximum updraft strengths in excess of $10 \mathrm{~m} \mathrm{~s}^{-1}$. Subsequently, the cloud development in terms of cloud base height, cloud top height and centre of the cloud mass $\left(Z_{\mathrm{c}}\right)$ as defined by Wu et al. (2009):

$Z_{\mathrm{c}}=\frac{\iint q_{t} z \mathrm{~d} x \mathrm{~d} z}{\iint q_{t} \mathrm{~d} x \mathrm{~d} z}$

where $z$ is the level and $\mathrm{d} x \mathrm{~d} z$ the integration area, are displayed in Fig. 4. We compare the 2-D case with the corresponding value of the 3-D simulation averaged over the additional dimension. There is little difference in the cloud base height, while cloud top heights and $Z_{\mathrm{c}}$ for the 3-D simulation are slightly higher than in the 2-D case, indicating stronger convection. This is also reflected in the deposited precipitation. At the same time, the timing of the precipitation with two distinct peaks is similar between the two cases. This is somewhat counter-intuitive, as one would expect increased entrainment for the 3-D case and less strong convection. 


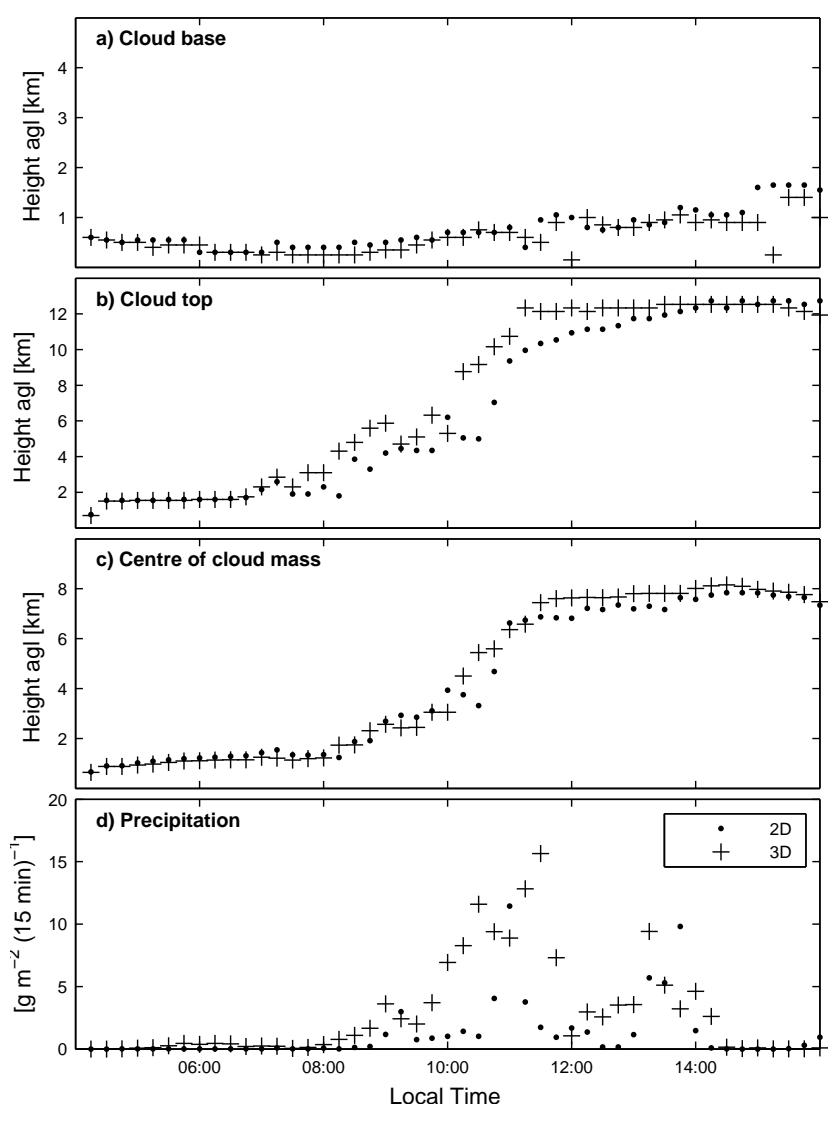

Figure 4. Comparison between the 2-D and 3-D simulation of case $2.0 \times$ FC for (a) cloud base height, (b) cloud top height, (c) the centre of cloud mass $\left(Z_{\mathrm{c}}\right.$ as defined in text) and (d) mean deposited precipitation.

However, due to the topographic forcing clouds are organised in bands so that entrainment is of less importance than anticipated. Our results are comparable to Garcia-Carreras et al. (2011), who also had stronger cloud development in the 3-D case. This might be due to the absence of lateral entrainment of dry air due to the limited extent and cyclic nature of the third dimension.

Despite some differences in the structure of convective evolution, the resulting convective development is sufficiently similar to focus on a 2-D approach to further evaluate the behaviour of the system.

\subsection{Turbulent fluxes}

We investigate the locally driven evolution from boundarylayer clouds to precipitating convection as is frequently observed at Nam Co Lake. Variation of initial soil moisture contents in Hybrid leads to a shift in the Bowen ratio. Figure 5 displays the diurnal cycle of the simulated median turbulent latent $\left(Q_{E}\right)$ and sensible heat fluxes $\left(Q_{\mathrm{H}}\right)$ as well as incoming solar radiation (SWD). The last panel shows the observed quantities at Nam Co station. As expected, the Bowen ratio changes from approx. 2.5 for the dry surface at PWP to 0.5 for the moist surface at $2.0 \times \mathrm{FC}$. While the incoming solar radiation initially follows the clear-sky radiation, there is a reduction of downward shortwave radiation seen in both the simulations and the measured fluxes after solar noon. This decrease in incoming solar radiation is the strongest for $1.0 \times \mathrm{FC}$, while $1.5 \times \mathrm{FC}$ and $2.0 \times \mathrm{FC}$ show a slightly weaker decline during the afternoon. This highlights the impact of soil moisture on cloud development. Larger latent heat fluxes lead to increased cloud formation, which is further discussed in the next sections. Solar radiation and surface fluxes were measured at Nam Co station, while the surface model calculated surface fluxes are for the total model domain. Due to the stochastic nature of turbulence, it is not meaningful to directly compare a single model grid cell to the measured data. However, it is possible to say that the median, simulated solar radiation flux within the Nam Co Basin for case $0.75 \times$ FC resembles most closely the measurements, while the moister cases have lower simulated solar irradiation. A comparison between the grid cell closest to the station and measurements (not shown) indicates that case $1.5 \times \mathrm{FC}$ matches most closely the observed fluxes in both terms of the Bowen ratio and the decrease of fluxes in the afternoon due to cloud cover, but the timing of the decrease was too early. At the same time there is large variation of fluxes as indicated by the interquartile difference, so that simulated solar radiation flux for all cases appears to be in reasonable agreement with the measured shortwave radiation.

The spatial variability of surface energy fluxes and solar radiation also demonstrates that surface atmosphere interactions change with increasing soil moisture. With the onset of cloud development, solar irradiance of shaded grid cells begins to drop, while the median irradiance and turbulent surface fluxes remain unaffected. With increasing cloud optical depth median shortwave radiation fluxes begin to decrease. This occurs first in the most shaded cells and then progresses to the mean fluxes. For the moister simulations $(1-2 \times \mathrm{FC})$ there is little difference between lower and upper quartile latent heat fluxes in the early afternoon, indicating widespread cloud cover as the main driver for the decrease. However, in the later afternoon, there is again increased variability in the simulated turbulent fluxes (both median and upper quartile) that is not accompanied by a corresponding increase in the median solar irradiation flux. This indicates that in addition to solar irradiance, local circulation systems likely play a role in the surface energy balance. The impact of local circulations on the surface energy balance, turbulent fluxes and convective triggering was investigated in Gerken et al. (2014).

Eddy-covariance measurements have a footprint area of similar magnitude to ATHAM's grid cells. Nevertheless, the same problem of comparing point measurements to a distributed simulation applies. Overall, there is a general agreement in the diurnal development of fluxes, with a decrease of turbulent fluxes in the afternoon. Case $2.0 \times \mathrm{FC}$ corresponds to a realistic surface initialisation. A comparison of simu- 


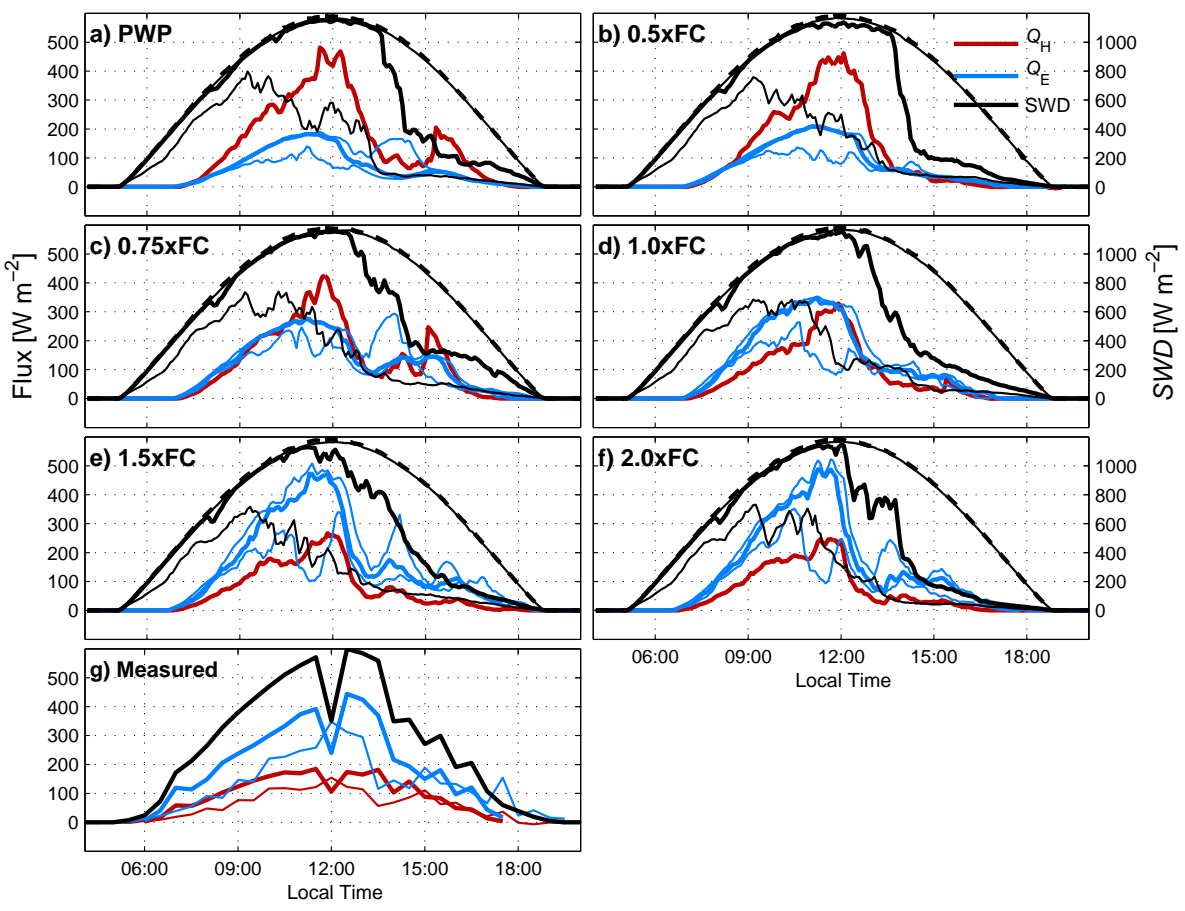

Figure 5. Development of turbulent surface fluxes in the Nam Co Lake basin for cases PWP, $0.5 \times$ FC, $0.75 \times$ FC, $1.0 \times$ FC, $1.5 \times$ FC and $2.0 \times$ FC on 17 July 2012 (a-e). Thick black lines correspond to the median flux over land. For SWD and $Q_{E}$ also the upper and lower quartiles are given as thin lines, presenting a measure of spatial flux variation. The dashed line is clear-sky SWD; (g) measured turbulent fluxes near Nam Co research station. Thin lines correspond to directly measured eddy-covariance fluxes. Thick lines are energy-balance corrected fluxes according to Twine et al. (2000).

lated and measured fluxes in Fig. $5 \mathrm{f}$ and g shows that measured median simulated fluxes in the afternoon are lower than the measured ones, while the maximum fluxes around noon show similar magnitudes. This is likely due to an overestimation in the simulated convective development that is caused by the lack of the third dimension and entrainment of dry air into convective thermals. The inherently unclosed nature of turbulent fluxes measured by the eddy-covariance technique (Foken, 2008) introduces an additional degree of uncertainty into the comparison of modelled and measured fluxes. The observed mean of the ground heat flux at the Nam Co station is of the order of $30 \%$ of net radiation (Biermann et al., 2014), leaving approx. $30 \%$ of the total surface energy balance unclosed. Using the energy balance correction of Twine et al. (2000) conserves the observed Bowen ratio, while the recently proposed buoyancy correction according to Charuchittipan et al. (2014) would attribute most of the unclosed flux to $Q_{h}$ and would thus change the Bowen ratio considerably. The Hybrid surface model was able to reproduce the turbulent flux measurement at the Nam Co station for a wide range of observed soil moisture (Gerken et al., 2012). Additionally, Kracher et al. (2009) showed that many landsurface models tend to reproduce measured Bowen ratios. As a consequence, we assume in this work that the Bowen ratio method of energy balance closure (Twine et al., 2000) is applicable and that there is an overall reasonable agree- ment between the diurnal evolution of modelled fluxes for the moister surface initialisations and the measured fluxes.

\subsection{Soil moisture-evapotranspiration response}

Immediately connected to turbulent flux dynamics and of central importance for the hydrological response of the Nam Co Basin is the question of the relationship between soil moisture and evapotranspiration. Figure 6 displays the soil moisture variables for the simulated cases. The first panel shows the development of soil moisture expressed as a function of field capacity for the upper model layer. From Fig. 6 it becomes apparent that evapotranspiration during the daytime has a large effect on modelled soil moisture. The surface model Hybrid has a comparatively simple treatment of soil moisture, which includes drainage, molecular diffusion between soil layers for transport and evapotranspiration and precipitation as sources and sinks. While there is a general decreasing tendency of soil moisture during the course of the simulations, precipitation events can replenish the soil with water. In the case of $1.0 \times \mathrm{FC}$, afternoon precipitation leads to soil moisture in the upper layer that are slightly larger than the initialised soil moisture and similar to soil moisture as in the moister $1.5 \times$ FC case.

Simulated evapotranspiration is expected to show a strong dependency on soil moisture for the relatively dry cases. 


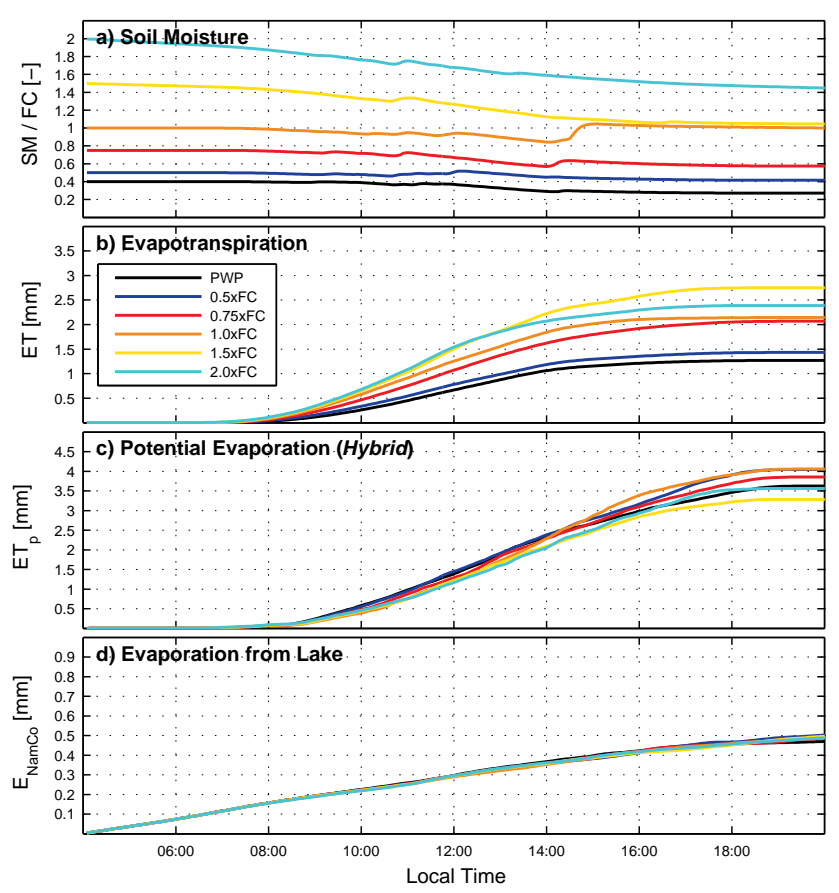

Figure 6. Moisture variables over time and averaged for Nam Co Basin for cases PWP, $0.5 \times$ FC, $0.75 \times$ FC, $1.0 \times$ FC, $1.5 \times$ FC and $2.0 \times$ FC on 17 July 2012: (a) soil moisture in terms of FC [-]; (b) integrated evapotranspiration [mm]; (c) integrated potential evaporation $[\mathrm{mm}]$ and $(\mathbf{d})$ integrated evaporation from Nam Co Lake [mm].

Indeed, there is a large increase in simulated evapotranspiration between cases $0.5 \times \mathrm{FC}$ and $0.75 \times \mathrm{FC}$, demonstrating a soil-moisture-limited regime as discussed in Seneviratne et al. (2010). A further doubling of soil moisture to $1.5 \times$ FC leads to a similarly big increase in evapotranspiration. This increase, however, is no longer true for the case $2.0 \times \mathrm{FC}$, which in fact has a lower actual evapotranspiration than the $1.5 \times \mathrm{FC}$ case. Between these two cases, the surface has switched from a moisture-limited regime to a radiation limited one due to an additional increase in cloud cover. At the same time, estimated potential evapotranspiration peaks for the $1.0 \times \mathrm{FC}$ case (Fig. 6c). Potential evapotranspiration, as calculated in Hybrid, is unlike the other quantities not a standard model output and had to be estimated with $5 \mathrm{~min}$ averaged model outputs, leading to some uncertainties in its magnitude. Nevertheless, it is striking that $1.0 \times \mathrm{FC}$ has the largest potential evapotranspiration, while $1.5 \times \mathrm{FC}$ and $2.0 \times \mathrm{FC}$ as the moistest cases in fact have the lowest. Additionally, for case $1.5 \times \mathrm{FC}$ actual evapotranspiration approaches potential evapotranspiration. In addition to the transition from a soil moisture-limited to a radiationlimited regime, there is also a feedback evident between soil moisture and convective development, which acts trough the generation of wind, precipitation and the reduction of in- coming shortwave radiation. This will be further discussed in Sect. 3.4.

There is little variation of evaporation from the lake surface between cases and total daytime evaporation is less than $0.5 \mathrm{~mm}$ (Fig. 6d) and thus $50 \%$ smaller than evapotranspiration from the land surface of even the driest case, highlighting the role of the land surface as a source of water. Additionally, the lake does not exhibit a strong diurnal pattern in simulated evaporation. This is in reasonable agreement to Biermann et al. (2014), who did not find a diurnal cycle in the measured lake evaporation.

Figure 7 shows the importance of soil moisture for the energy balance of the Nam Co Basin. Turbulent surface fluxes are integrated over space and time. The surface energy balance on the Tibetan Plateau is of key importance for understanding hydrological processes. Due to the clean atmosphere (i.e. Cong et al., 2009) at Nam Co Lake and its high elevation, the fraction of diffuse to direct radiation is small compared to more polluted environments so that clouds, through modification of the net radiation, have a stronger influence on the surface energy balance than in other regions. Soil moisture strongly modifies the partitioning of the available energy into sensible and latent heat, evident in the Bowen ratio, and thus the surface energy balance. We separated the integrated surface energy fluxes into the area of the lake, the non-elevated land around the lake, referred to as plain, the Nam Co Basin, which is defined from the lake to the top of the Nyenchen Thangla and an equal extent on the northern side of the lake. For completeness the whole domain values are also presented. Overall, sensible heat fluxes from the lake are negligible, while the importance of Nam Co Lake for latent energy fluxes compared with the plain area is very dependent on the initial soil moisture conditions: for the cases PWP and $0.5 \times$ FC integrated latent heat fluxes from the lake have almost the same magnitude as the fluxes from the plain area, whereas for the moister cases they are comparatively small. As a consequence the importance of the lake as a moisture source for the surrounding area decreases with moister environmental conditions.

In general, there is a rather complicated behaviour of integrated energy fluxes for the plain and the basin area, which must be attributed to local dynamics such as the lake breeze, cloud cover and the evolution of convection. The $1.5 \times$ FC has the largest transfer of latent energy from the land surface to the atmosphere, while the moister $2.0 \times \mathrm{FC}$ case has a smaller transfer of both latent and sensible energy. After 12:00 LT there is a visible change in the slope for $2.0 \times \mathrm{FC}$, which is associated with increased cloud cover, while a similar kink for $1.5 \times \mathrm{FC}$ and $1.0 \times \mathrm{FC}$ is less strong. For $0.75 \times \mathrm{FC}$ there is a different behaviour. While there is also a reduction in fluxes after 12:00 LT, but unlike the moister cases, this results in only a temporary reduction in the surface to atmosphere transfer of latent heat which then increases again, while the transfer of sensible heat is as large as for case $0.5 \times \mathrm{FC}$. 

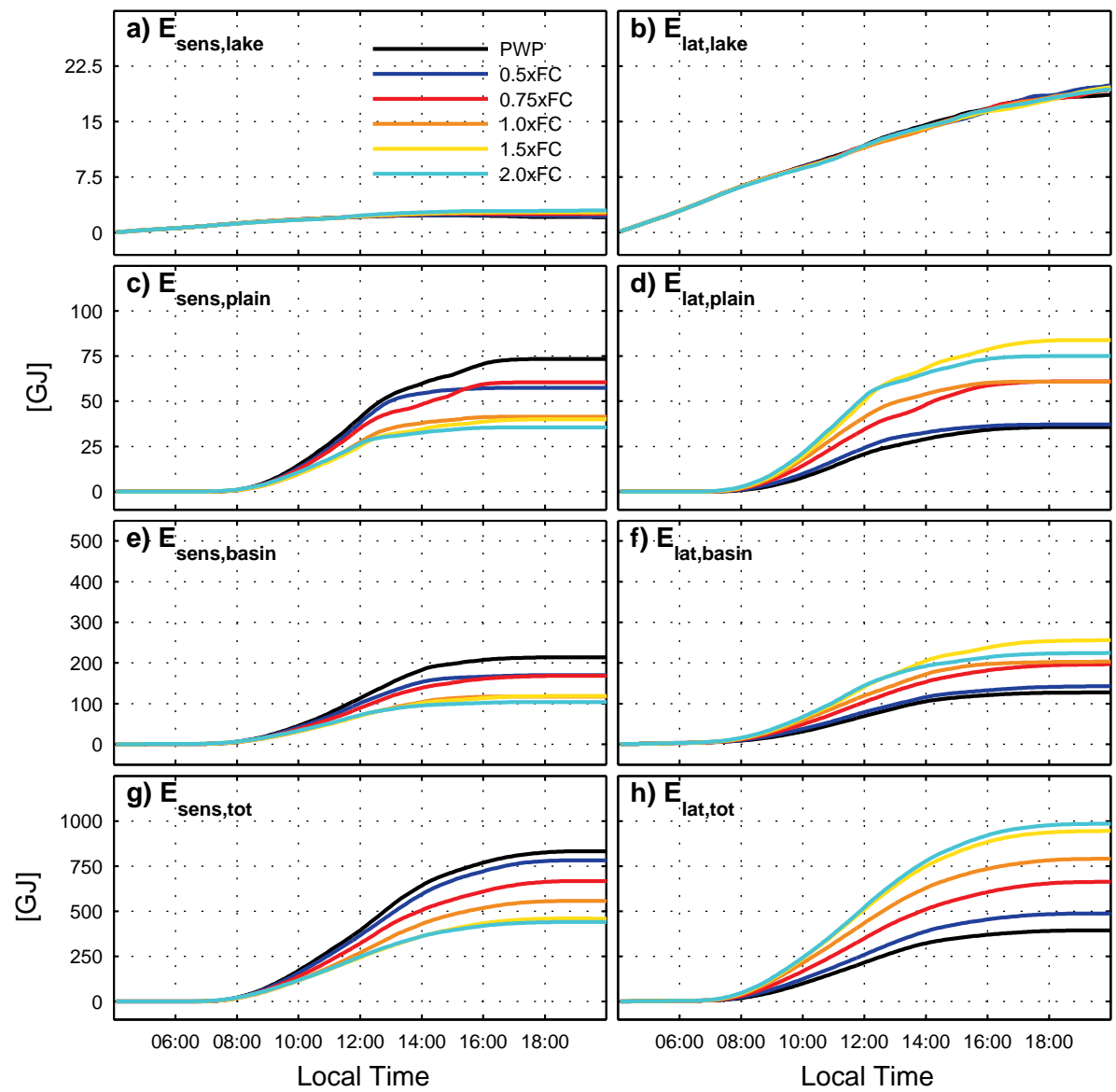

Figure 7. Spatially and temporally integrated turbulent energy fluxes $(E)$ at Nam Co Lake for cases PWP, $0.5 \times \mathrm{FC}, 0.75 \times \mathrm{FC}, 1.0 \times \mathrm{FC}$, $1.5 \times \mathrm{FC}$ and $2.0 \times \mathrm{FC}$ on 17 July 2012: (a, b) sensible and latent energy over the lake, (c, d) over the plain adjacent to the lake, (e, f) the Nam Co Basin as defined in the text and $(\mathbf{g}, \mathbf{h})$ in total domain.

\subsection{Convective development}

We investigated the development of locally developed convection as it is frequently observed in the Nam Co Lake basin. As discussed in Sect. 3.2 there is a direct interaction between soil moisture, Bowen ratio and turbulent surface fluxes, which to a large extent drives convective evolution. Therefore, differences in convective development are expected for the simulated cases.

During the course of the day, boundary-layer clouds forming at the beginning of the simulation grow into moist deep convection that produces precipitation in the model domain. Figure 8 displays the simulated averaged cloud liquid water concentration, as well as $Z_{\mathrm{c}}$, cloud base and cloud top height. While all simulations lead to the development of deep convection, there are some differences in the amount of generated convection, the convective timing and dynamics as well as deposited precipitation (Sect. 3.5). The drier PWP and $0.5 \times$ FC cases show only limited or isolated convection before solar noon and then some deeper convection around 14:00 LT, which does not lead to strong precipita- tion. Cases $0.75 \times \mathrm{FC}$ and $1.0 \times \mathrm{FC}$ on the other hand have a slightly stronger and earlier triggering of convection and then a stronger release of convective energy in the afternoon that is accompanied by a distinct precipitation event. The moistest simulations (cases $1.5 \times \mathrm{FC}$ and $2.0 \times \mathrm{FC}$ ) have a stronger cloud development before noon and then lack a strong convective triggering in the afternoon.

These three regimes become especially visible, when analysing the convective mass flux $M_{\mathrm{c}}$ defined as the product of moist density $(\rho)$ and vertical velocity $(w)$ integrated for a given height $z$ :

$M_{\mathrm{c}}(z)=\int \rho w \mathrm{~d} A$,

and integrated over cloudy grid cells with $w>0$ (Fig. 9). Cases $0.75 \times \mathrm{FC}$ and $1.0 \times \mathrm{FC}$ are the only simulations that show a peak in convective mass flux in the afternoon at $5 \mathrm{~km}$ and $7 \mathrm{~km}$ a.g.l., while the remaining simulations show a different evolution. As the development of deep convection is sustained by the release of latent energy, it is expected to gain strength with height until latent energy release becomes 


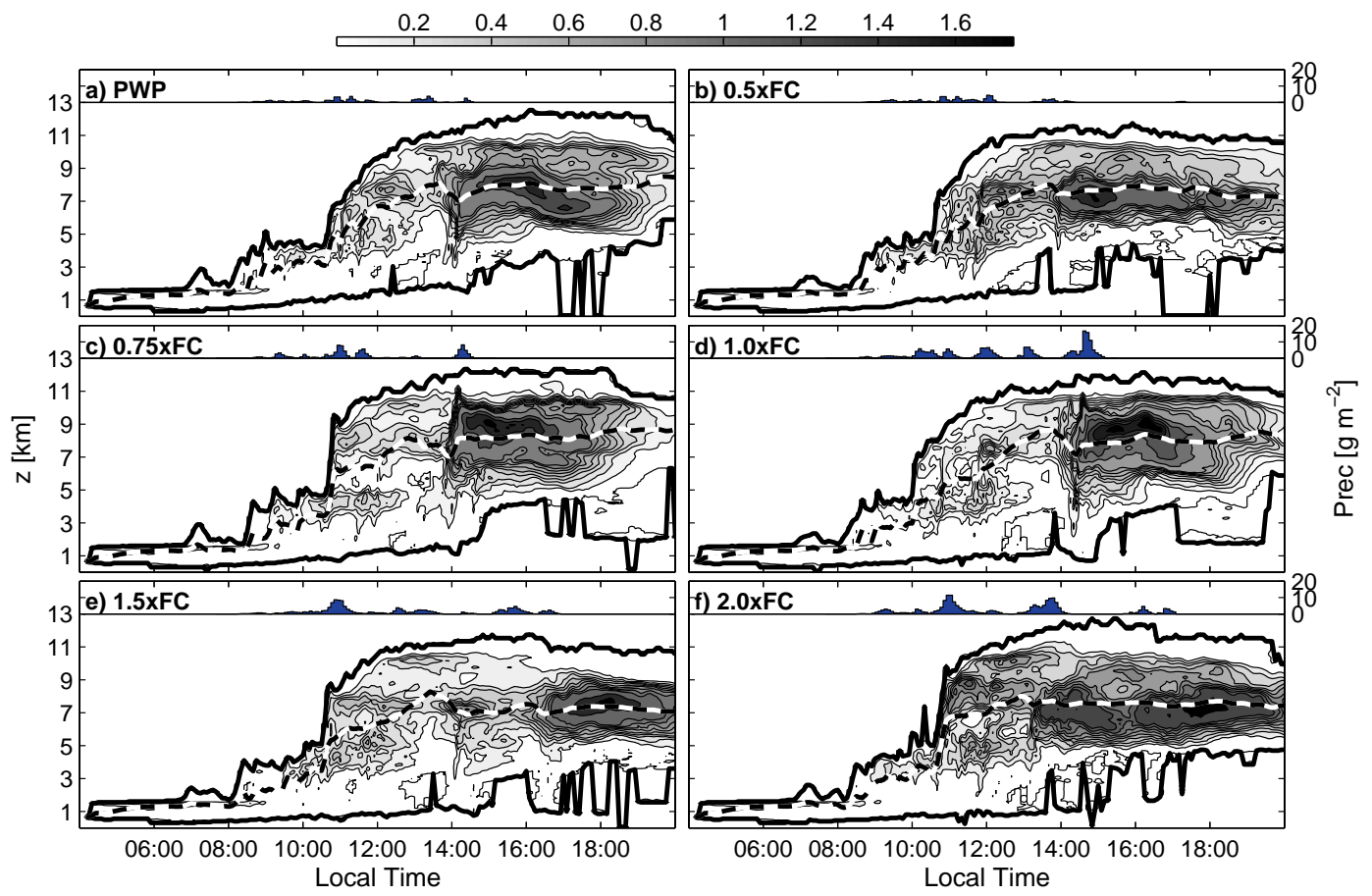

Figure 8. Modelled development of convection at Nam Co Lake for cases PWP, $0.5 \times \mathrm{FC}, 0.75 \times \mathrm{FC}, 1.0 \times \mathrm{FC}, 1.5 \times \mathrm{FC}$ and $2.0 \times \mathrm{FC}$ on 17 July 2012: contours correspond to mean cloud water equivalent concentrations in the Nam Co Lake basin [ $\mathrm{g} \mathrm{m}^{-3}$ ]. The dashed line indicates the height of the centre of cloud mass $\left(Z_{\mathrm{c}}\right)$ and black lines indicate cloud top and cloud bottom heights. The upper panel of each subplot indicates mean deposited precipitation within each $5 \mathrm{~min}$ interval $\left[\mathrm{g} \mathrm{m}^{-2}\right]$.

smaller than the reduction of buoyancy by the entrainment of dry air. Overall, there is little difference in $M_{\mathrm{c}}$ at $3 \mathrm{~km}$ between the cases, but the dry cases lack the moisture for a subsequent release of latent energy and strong convection in the afternoon. It should be noted that the initial profile is quite moist for the lowermost $3 \mathrm{~km}$, but then there is a dry zone between 3 and $6 \mathrm{~km}$ a.g.l. The equivalent potential temperature profile $\left(\theta_{\mathrm{e}}\right)$ reveals a predisposition for convection. Hence, comparatively large $Q_{E}$ fluxes are necessary to provide the atmosphere with sufficient moisture for the development of convection and the release of latent heat. At the same time, the moister simulations also do not develop strong deep convection, as they have the smallest convective mass flux at $3 \mathrm{~km}$ around 14:00 LT. This means that the cloud cover displayed in Fig. 8e and $\mathrm{f}$ develops earlier and is not associated with strong convective motion. At the same time, the cloud base height decreases with increasing moisture as more water vapour accumulates in the boundary layer, which is consistent with the investigation by Golaz et al. (2001) and Yamada (2008), who also found a decreased buoyancy for their wet surface case. Furthermore, for the intermediate cases, local differences in precipitation affect surface moisture and potentially induce circulations that lead to additional convection triggering (Clark et al., 2004).

An analysis of convective available potential energy (CAPE) tells a similar story (Fig. 10). After sunrise, simulated CAPE values in the Nam Co start to diverge between cases due to differences in the surface energy balance. Cases PWP and $0.75 \times \mathrm{FC}$ develop the least amount of CAPE, which is fully released between 09:00 and 14:00 LT. The moistest cases in contrast develop the largest amounts of CAPE, but it is not fully released as high soil moisture and associated lack of sensible heat fluxes reduce convection development. Consequently, CAPE is exported from the basin. Cases $0.75 \times$ FC and $1.0 \times$ FC present an intermediate, for which there is ample development of CAPE, which is almost fully depleted by convection during the afternoon, so that they have the highest overall release of CAPE.

Overall, there are three different regimes of convective development in the simulations for Nam Co Lake that are associated with soil moisture. Convective development requires the availability of moisture and vertical instability through surface heating, and these conditions are best met for the intermediate moisture cases, while the drier cases do not provide a strong enough moistening and the moister cases inhibit the development of vertical motion due to increase cloud cover and lack of surface heating.

\subsection{Precipitation and atmospheric moisture transport}

The development of convection at Nam Co Lake is associated with daytime precipitation. Several studies have addressed the mechanisms of precipitation development in Ti- 

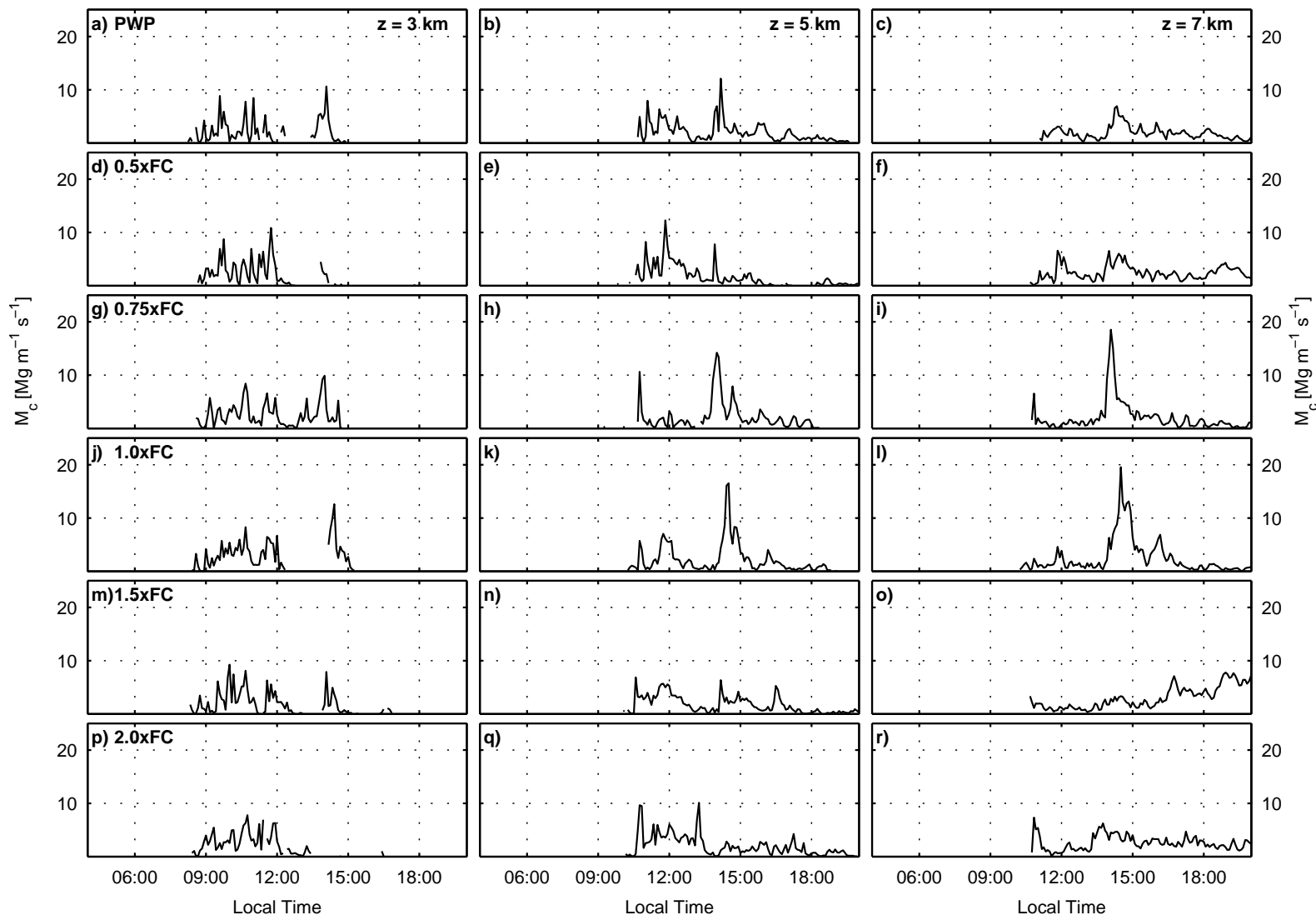

Figure 9. Convective mass flux at 3, 5 and $7 \mathrm{~km}$ a.g.l. for cases PWP, $0.5 \times \mathrm{FC}, 0.75 \times \mathrm{FC}, 1.0 \times \mathrm{FC}, 1.5 \times \mathrm{FC}$ and $2.0 \times \mathrm{FC}$ on 17 July 2012 .

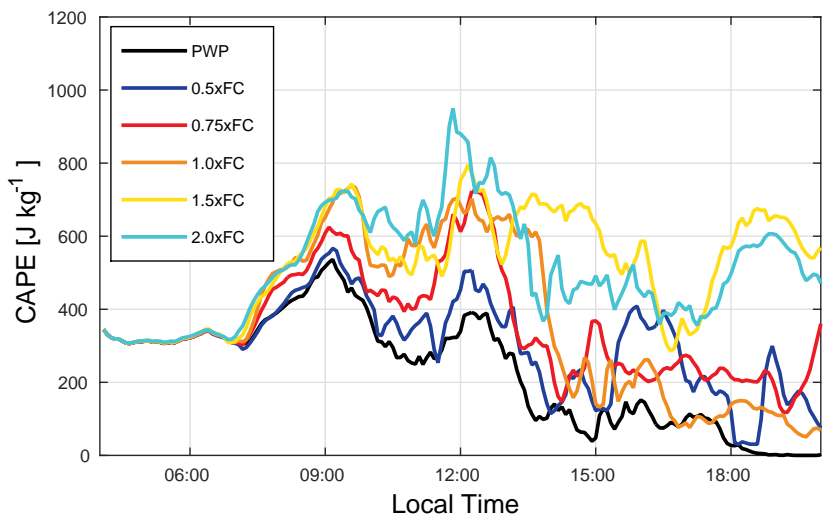

Figure 10. Temporal development of simulated Convective Available Potential Energy (CAPE, $\left[\mathrm{J} \mathrm{kg}^{-1}\right]$ ) within the Nam Co Lake basin for cases PWP, $0.5 \times \mathrm{FC}, 0.75 \times \mathrm{FC}, 1.0 \times \mathrm{FC}, 1.5 \times \mathrm{FC}$ and $2.0 \times$ FC on 17 July 2012 .

betan valleys (e.g. Kurita and Yamada, 2008; Ueno et al., 2009). In addition to precipitation from mesoscale convective systems there are two types of locally developed precipitation: (1) daytime isolated convection triggered over the mountain chains or, in the case of Nam Co Lake, at the collision front between the lake breeze and the geostrophic wind
(Gerken et al., 2013a) and (2) convergence in the centre of the valleys through thermal circulations leading to night-time precipitation. Due to the nature of our study, we only discuss the effects of locally generated, daytime precipitation.

As was demonstrated in Sect. 3.3 locally generated precipitation has a large influence on the availability of soil moisture and thus on surface fluxes. This is of special importance since potential evaporation rates of approx. $4 \mathrm{~mm} \mathrm{day}^{-1}$ are of similar magnitude to the water that is stored in the uppermost $10 \mathrm{~cm}$ of the soil at field capacity. Actual evaporation rates for a Kobresia meadow were measured at 2 to $6 \mathrm{~mm} \mathrm{day}^{-1}$ (Babel et al., 2014). Therefore, the water balance of the Nam Co Basin and the regional transport of water vapour are of importance. Due to the simple Kessler-type microphysics used in this study, the actual precipitation rates only allow for a qualitative comparison between cases.

Table 2 displays the deposited precipitation for the convection simulations in terms of absolute mass and as fraction of evapotranspiration. For the entire domain between 6 and $10 \%$ of the moisture evapotranspiration is deposited as precipitation. These values are smaller than commonly reported. This is at least partially due to the integration time of our simulations, which is shorter than the typical residence time of atmospheric water vapour. The lake surface has the 
Table 2. Total simulated deposited precipitation (Prec, $\left[\mathrm{g} \mathrm{m}^{-2}\right]$ ) and normalised by evapotranspiration (Prec/ET [-]) for cases PWP, $0.5 \times$ FC, $0.75 \times \mathrm{FC}, 1.0 \times \mathrm{FC}, 1.5 \times \mathrm{FC}$ and $2.0 \times \mathrm{FC}$ on 17 July 2012 for lake area, the plain adjacent to lake, the Nam Co Basin as defined in the text and the total domain. The area definitions are the same as those used in Fig. 7.

\begin{tabular}{|c|c|c|c|c|c|c|c|c|}
\hline \multirow[t]{2}{*}{ Case } & \multicolumn{2}{|c|}{ Lake } & \multicolumn{2}{|c|}{ Plain } & \multicolumn{2}{|c|}{ Basin } & \multicolumn{2}{|c|}{ Domain } \\
\hline & $\begin{array}{r}\text { Prec } \\
{\left[\mathrm{g} \mathrm{m}^{-2}\right]}\end{array}$ & $\begin{array}{c}\text { Prec/ET } \\
{[-]}\end{array}$ & $\begin{array}{r}\text { Prec } \\
{\left[\mathrm{g} \mathrm{m}^{-2}\right]}\end{array}$ & $\begin{array}{c}\text { Prec/ET } \\
{[-]}\end{array}$ & $\begin{array}{c}\text { Prec } \\
{\left[\mathrm{g} \mathrm{m}^{-2}\right]}\end{array}$ & $\begin{array}{c}\text { Prec/ET } \\
{[-]}\end{array}$ & $\begin{array}{r}\text { Prec } \\
{\left[\mathrm{g} \mathrm{m}^{-2}\right]}\end{array}$ & $\begin{array}{c}\text { Prec/ET } \\
{[-]}\end{array}$ \\
\hline PWP & 6 & 0.01 & 115 & 0.09 & 103 & 0.10 & 65 & 0.06 \\
\hline $0.5 \times \mathrm{FC}$ & 5 & 0.01 & 81 & 0.06 & 154 & 0.13 & 74 & 0.06 \\
\hline $0.75 \times \mathrm{FC}$ & 55 & 0.11 & 224 & 0.11 & 194 & 0.12 & 103 & 0.06 \\
\hline $1.0 \times \mathrm{FC}$ & 40 & 0.08 & 244 & 0.12 & 393 & 0.24 & 204 & 0.10 \\
\hline $1.5 \times \mathrm{FC}$ & 47 & 0.09 & 315 & 0.11 & 176 & 0.09 & 153 & 0.06 \\
\hline $2.0 \times \mathrm{FC}$ & 216 & 0.44 & 355 & 0.14 & 271 & 0.15 & 201 & 0.08 \\
\hline
\end{tabular}

Table 3. Total integrated moisture flux $\left(F_{q}\right)$ into Nam Co Lake basin between 06:00 and 16:00 BST. The control domains denoted with subscripts A and B are indicated in Fig. 11g. The subscripts Nw, Se stand for the north-west and south-east boundaries. Positive fluxes across the lateral boundaries indicate flux into the domain. ET and $P$ are the evapotranspiration and precipitation flux; 3 and 10 indicate the vertical boundaries of the control volumes, with a negative sign for upward flux. $\Delta q_{\text {tot }}$ is the total net moisture flux for a volume.

\begin{tabular}{|c|c|c|c|c|c|c|c|c|c|c|}
\hline \multirow[b]{3}{*}{ Case } & \multicolumn{5}{|c|}{ Domain A } & \multirow{2}{*}{\multicolumn{3}{|c|}{ Domain B }} & \multirow[b]{3}{*}{$\begin{array}{r}\Delta q_{\mathrm{tot}, \mathrm{A}} \\
{[\mathrm{Mg}]}\end{array}$} & \multirow[b]{3}{*}{$\begin{array}{r}\Delta q_{\text {tot, } \mathrm{B}} \\
{[\mathrm{Mg}]}\end{array}$} \\
\hline & \multirow[b]{2}{*}{$F_{q, \mathrm{ANw}}$} & \multirow[b]{2}{*}{$\begin{array}{l}F_{q, \mathrm{ASe}} \\
\quad[\mathrm{Mg}]\end{array}$} & \multirow[b]{2}{*}{$F_{q, \mathrm{ET}}$} & \multirow[b]{2}{*}{$F_{q, \mathrm{P}}$} & & & & & & \\
\hline & & & & & $F_{q, 3}$ & $F_{q, 10}$ & $\begin{array}{l}F_{q, \mathrm{BNw}} \\
{[\mathrm{Mg}]}\end{array}$ & $F_{q, \mathrm{BSe}}$ & & \\
\hline PWP & 1351.8 & -1382.4 & 51.4 & -5.2 & 99.3 & -2.3 & 244.3 & -332.1 & -83.7 & 9.2 \\
\hline $0.5 \times \mathrm{FC}$ & 1367.1 & -1360.9 & 57.6 & -7.8 & 128.4 & -3.9 & 279.4 & -350.3 & -72.4 & 53.6 \\
\hline $0.75 \times \mathrm{FC}$ & 1473.4 & -1449.0 & 79.4 & -9.8 & 166.3 & -9.5 & 181.7 & -332.8 & -72.4 & 5.7 \\
\hline $1.0 \times \mathrm{FC}$ & 1438.7 & -1438.0 & 81.9 & -19.9 & 167.1 & -0.1 & 256.0 & -372.8 & -104.4 & 50.1 \\
\hline $1.5 \times \mathrm{FC}$ & 1432.8 & -1430.0 & 103.2 & -8.9 & 124.7 & -3.4 & 324.2 & -355.6 & -27.6 & 89.9 \\
\hline $2.0 \times \mathrm{FC}$ & 1422.6 & -1417.0 & 90.5 & -13.7 & 129.7 & -6.5 & 334.8 & -366.4 & -47.3 & 91.6 \\
\hline
\end{tabular}

largest spread with 1 to $44 \%$ of recycled water. In general, the lake surface receives comparatively less precipitation per area than the rest of the basin, which is in line with expectations, as a cool water body suppresses convective activity. We observe increasing precipitation with increasing soil moisture. This trend is most clear for the driest cases, while it becomes less apparent for the moistest cases. This is in accordance with the observations of convective activity, which are strongest for intermediate initial soil moisture. Additionally, the basin and the plain are over-represented in terms of deposited precipitation in comparison to the total domain.

A closer investigation into the moisture budget of the Nam Co Lake basin (Fig. 11) further points to the importance of vertical moisture transport within the region. We define two control domains for the Nam Co Basin: control domain A corresponds to the lowermost $3 \mathrm{~km}$ a.g.l., while control domain B is located directly above and extends to $10 \mathrm{~km}$. The horizontal extent of the control domains is from the centre of the model domain to the top of the Nyenchen Thangla mountain chain and a similar extent to the north-west (see also Fig. 11g for illustration). It becomes apparent that the vertical transport of moisture dominates the overall mois- ture budget of both control domains for all displayed simulations, while evapotranspiration and precipitation are comparatively small terms. This leads to a net decrease of moisture in the lower control domain A during the daytime. During the night-time a reversal of the thermal circulation and subsidence should lead to a balancing of the moisture budget, which is not included in our simulations. Table 3 presents the full moisture balance for all cases. The convective transport from domain $\mathrm{A}$ to domain $\mathrm{B}$ is the strongest for $0.75 \times \mathrm{FC}$ and $1.0 \times \mathrm{FC}$, while the remaining cases are of similar magnitude, underpinning again the preferential convective development for intermediate soil moisture. Lateral moisture transport, or advection is of only small importance for the lower control domain as the net flux is small. Vertical moisture transport dominates for domain A and it is the primary source of moisture for domain B. In the afternoon, when convective activity ceases, the moisture budget of the upper domain becomes increasingly more dominated by lateral transport of moisture with the background wind. This signifies that clouds and water vapour are removed from the basin, indicating locally occurring convection as a source of moisture for the larger region. However, as previously mentioned, the 


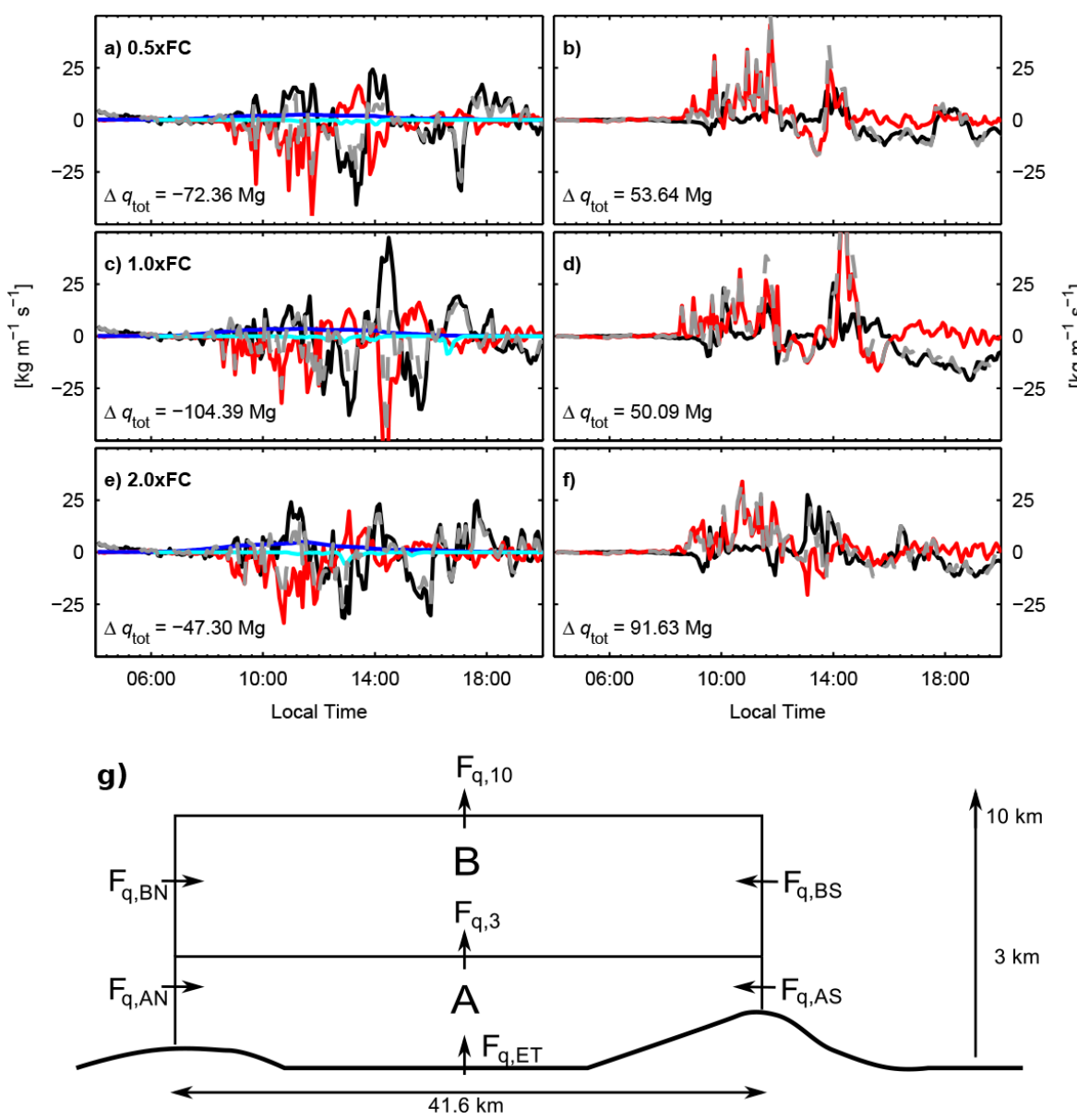

Figure 11. Instantaneous moisture flux $f_{q}\left[\mathrm{~kg} \mathrm{~m}^{-1} \mathrm{~s}^{-1}\right]$ for Nam Co Lake basin. (a, c, e) Moisture transport into control volume A, as indicated in (g) of this figure, representing the Nam Co Basin up to $3 \mathrm{~km}$ a.g.l.: evapotranspiration (blue); precipitation (cyan); net horizontal flux (black); net vertical flux (red); and resulting total flux (grey, dashed). The precipitation flux is not displayed as it is of negligible magnitude. (b, d, f) Transport into the mid-tropospheric control volume B with the same horizontal extent and from 3 to $10 \mathrm{~km}$ vertical extent; $(\mathbf{g})$ is a schematic drawing of the control volumes.

upper level wind speeds used in this work are unrealistically low, so that under realistic conditions one would expect an even faster transport of moisture from the basin to the surrounding area. Recent work by Froidevaux et al. (2013) investigated the importance of background wind speeds and horizontal transport of convective cells during their development. While wind speeds used in this work were lower than observed, the lake-land circulation (i.e. Gerken et al., 2014) provides the necessary horizontal propagation mechanism that allows for the development of convective cells.

\section{Conclusions}

In this work we have used the high-resolution atmospheric model ATHAM, coupled with the Hybrid surface model, to investigate the influence of soil moisture on convective development in the Nam Co Lake area. Surface moisture and, thus, turbulent fluxes are highly variable on the Tibetan Plateau and, therefore, not only are important for the Bowen ratio and the surface energy balance, but also have an effect on atmospheric dynamics.

It was established in this work as well as in previous studies that the modelling system used in this investigation is a sensible and cost-effective approach for the most important processes with regard to surface-atmosphere interactions, the evolution from boundary-layer clouds to deep and moist convection, and its interaction with background winds and complex topography.

The ATHAM model, with a fully coupled surface, was used to investigate surface-atmosphere interactions in a cross section through the Nam Co Lake basin for simulations with different initialised soil moisture. The model produces realistic turbulent energy fluxes of latent and sensible heat. The reduction in surface moisture leads to a shift in the Bowen ratio from 0.5 to 2.5 . The fluxes of the most realistic surface configuration are in reasonable agreement to measured fluxes at 
Nam Co station. There is a feedback between surface fluxes, cloud cover and convection. Larger latent heat fluxes lead to increased cloud cover and consequently to smaller net surface radiation. This is seen in the simulated evapotranspiration. The surface changes from a water limited to a radiationlimited evapotranspiration regime, so that increased moisture actually means smaller net surface radiation. The role of the lake as a source of moisture depends on the initial surface moisture. Latent heat fluxes from the lake have a substantial contribution to the overall water budget of the basin only for very dry land surfaces. Our research clearly demonstrates the importance of soil moisture for the overall surface energy balance of the lake system and thus for potentially wider implications for the Tibetan Plateau's energy balance as a whole.

We subsequently investigated convective development and convective mass fluxes and found a "convective optimum" for the Nam Co Lake basin at intermediate soil moisture. At small soil moisture there is insufficient moisture available for latent heat release, which drives convection in the conditionally unstable Tibetan atmosphere. At very high soil moisture there is increased cloud cover, small sensible heat fluxes and decreased vertical motion. So while precipitation does occur, there is little convective development.

This has implications for the moisture budget of the Nam Co Basin. We found that the basin itself and especially the plain and the mountains are a preferential area for precipitation so that weather stations close to the lake are not representative for the entire basin. At the same time vertical transport of moisture through convection and the subsequent lateral transport with the background wind, may be an important water source for the larger region. Overall, precipitation effects can be directly seen in the soil moisture response of the coupled model and thus have an influence on turbulent fluxes, convective development and the surface energy balance. As precipitation events are both small in scale and short in duration, it is extremely important to get a good representation of regional precipitation in time as well as location. This requires mesoscale models at the appropriate resolutions of the order of a few hundred metres. Additionally, both Hohenegger et al. (2009) and our previous work (Gerken et al., 2013a) highlight the importance of atmospheric profiles, through stability and convective inhibition, in the triggering of convection. This demonstrates a further need for accurate high-resolution data sets for soil and atmospheric data.

As current environmental impacts, such as climate change and land use change, not only are expected to impact surface cover and soil moisture, but also it is important to assess how these changes will affect convective development and thus the hydrological cycle on the Tibetan Plateau.
Acknowledgements. This research was funded by the German Research Foundation (DFG) Priority Programme 1372 "Tibetan Plateau: Formation, Climate, Ecosystems" as part of the Atmosphere-Ecology-Glaciology-Cluster (TiP-AEG): FO 226/181,2. The work described in this publication has been supported by the European Commission (Call FP7-ENV-2007-1 grant no. 212921) as part of the CEOP-AEGIS project coordinated by the University of Strasbourg. The map of Nam Co was produced by Sophie Biskop (University of Jena) and Jan Kropacek (University of Tübingen) within DFG-TiP and Phil Stickler of the Cambridge Geography Department Cartography Unit. This publication was funded by the German Research Foundation (DFG) and the University of Bayreuth in the funding programme Open-Access Publishing.

Edited by: A. Loew

\section{References}

Babel, W., Biermann, T., Coners, H., Falge, E., Seeber, E., Ingrisch, J., Schleuß, P.-M., Gerken, T., Leonbacher, J., Leipold, T., Willinghöfer, S., Schützenmeister, K., Shibistova, O., Becker, L., Hafner, S., Spielvogel, S., Li, X., Xu, X., Sun, Y., Zhang, L., Yang, Y., Ma, Y., Wesche, K., Graf, H.-F., Leuschner, C., Guggenberger, G., Kuzyakov, Y., Miehe, G., and Foken, T.: Pasture degradation modifies the water and carbon cycles of the Tibetan highlands, Biogeosciences, 11, 6633-6656, doi:10.5194/bg-11-6633-2014, 2014.

Banta, R. M. and Barker Schaaf, C.: Thunderstorm Genesis Zones in the Colorado Rocky Mountains as determined by traceback of geosynchronous satellite Images, Mon. Weather Rev., 115, 463-476, doi:10.1175/15200493(1987)115<0463:TGZITC>2.0.CO;2, 1987.

Barthlott, C., Hauck, C., Schädler, G., Kalthoff, N., and Kottmeier, C.: Soil moisture impacts on convective indices and precipitation over complex terrain, Meteorol. Z., 20, 185-197, doi:10.1127/0941-2948/2011/0216, 2011.

Biermann, T., Babel, W., Olesch, J., and Foken, T.: Mesoscale Circulations and Energy and Gas Exchange over the Tibetan Plateau - Documentation of the Micrometeorological Experiment, Nam Tso, Tibet, 25 June-8 August 2009, Arbeitsergebnisse 41, University of Bayreuth, Bayreuth, 2009.

Biermann, T., Babel, W., Ma, W., Chen, X., Thiem, E., Ma, Y., and Foken, T.: Turbulent flux observations and modelling over a shallow lake and a wet grassland in the Nam Co basin, Tibetan Plateau, Theor. Appl. Climatol., 116, 301-316, doi:10.1007/s00704-013-0953-6, 2014.

Boos, W. R. and Kuang, Z.: Dominant control of the South Asian monsoon by orographic insulation versus plateau heating, Nature, 463, 218-222, doi:10.1038/nature08707, 2010.

Charuchittipan, D., Babel, W., Mauder, M., Leps, J.-P., and Foken, T.: Extension of the averaging time of the eddy-covariance measurement and its effect on the energy balance closure, Bound.-Lay. Meteorol., 152, 303-327, doi:10.1007/s10546-0149922-6, 2014.

Che, M., Chen, B., Innes, J. L., Wang, G., Dou, X., Zhou, T., Zhang, H., Yan, J., Xu, G., and Zhao, H.: Spatial and temporal variations in the end date of the vegetation growing season 
throughout the Qinghai-Tibetan Plateau from 1982 to 2011, Agr. Forest Meteorol., 189-190, 81-90, 2014.

Cheng, W. Y. Y. and Cotton, W. R.: Sensitivity of a CloudResolving Simulation of the Genesis of a Mesoscale Convective System to Horizontal Heterogeneities in Soil Moisture Initialization, J. Hydrometeorol., 5, 934-958, doi:10.1175/15257541(2004)005<0934:SOACSO>2.0.CO;2, 2004.

Cheng, G. and Wu, T.: Responses of permafrost to climate change and their environmental significance, Qinghai-Tibet Plateau, J. Geophys. Res., 112, F02S03, doi:10.1029/2006JF000631, 2007.

Clark, D. B., Taylor, C. M., and Thorpe, A. J.: Feedback between the land surface and rainfall at convective length scales, J. Hydrometeorol., 5, 625-639, doi:10.1175/15257541(2004)005<0625:FBTLSA>2.0.CO;2, 2004.

Cong, Z., Kang, S., Smirnov, A., and Holben, B.: Aerosol optical properties at Nam $\mathrm{Co}$, a remote site in central Tibetan Plateau, Atmos. Res., 92, 42-48, doi:10.1016/j.atmosres.2008.08.005, 2009.

Cui, X. and Graf, H.-F.: Recent land cover changes on the Tibetan Plateau: a review, Climatic Change, 94, 47-61, doi:10.1007/s10584-009-9556-8, 2009.

Cui, X., Graf, H.-F., Langmann, B., Chen, W., and Huang, R.: Climate impacts of anthropogenic land use changes on the Tibetan Plateau, Global Planet. Change, 54, 33-56, doi:10.1016/j.gloplacha.2005.07.006, 2006.

Fairall, C. W., Bradley, E. F., Godfrey, J. S., Wick, G. A., Edson, J. B., and Young, G. S.: Cool-skin and warm-layer effects on sea surface temperature, J. Geophys. Res., 101, 1295-1308, 1996a.

Fairall, C. W., Bradley, E. F., Rogers, D. P., Edson, J. B., and Young, G. S.: Bulk parameterization of air-sea fluxes for Tropical Ocean-Global Atmosphere Coupled-Ocean Atmosphere Response Experiment, J. Geophys. Res., 101, 3747-3764, 1996 b.

Fischer, E. M., Seneviratne, S. I., Vidale, P. L., Lüthi, D., and Schär, C.: Soil moisture-atmosphere interactions during the 2003 European summer heat wave, J. Climate, 20, 5081-5099, doi:10.1175/JCLI4288.1, 2007.

Flohn, H.: Hochgebirge und allgemeine Zirkulation, Arch. Meteor. Geophy. A, 5, 265-279, doi:10.1007/BF02247771, 1952.

Foken, T.: The energy balance closure problem: an overview, Ecol. Appl., 18, 1351-1367, 2008.

Foken, T. and Falke, H.: Technical Note: Calibration device for the krypton hygrometer KH20, Atmos. Meas. Tech., 5, 1861-1867, doi:10.5194/amt-5-1861-2012, 2012.

Foken, T., Aubinet, M., Finnigan, J. J., Leclerc, M. Y., Mauder, M., and Paw, U. K. T.: Results of a panel discussion about the energy balance closure correction for trace gases, B. Am. Meteorol. Soc., 92, ES13-ES18, doi:10.1175/2011BAMS3130.1, 2011.

Foken, T., Leuning, R., Oncley, S. R., Mauder, M., and Aubinet, M.: Corrections and data quality control, in: Eddy Covariance, edited by: Aubinet, M., Vesala, T., and Papale, D., Springer Atmospheric Sciences, Springer, Dordrecht, 85-131, doi:10.1007/97894-007-2351-1_4, 2012.

Friend, A. D. and Kiang, N. Y.: Land surface model development for the GISS GCM: effects of improved canopy physiology on simulated climate, J. Climate, 18, 2883-2902, doi:10.1175/JCLI3425.1, 2005.

Friend, A. D., Stevens, A. K., Knox, R. G., and Cannell, M. G. R.: A process-based, terrestrial biosphere model of ecosystem dynamics (Hybrid v3.0), Ecol. Model., 95, 249-287, doi:10.1016/S0304-3800(96)00034-8, 1997.

Froidevaux, P., Schlemmer, L., Schmidli, J., Langhans, W., and Schär, C.: Influence of the background wind on the local soil moisture-precipitation feedback, J. Atmos. Sci., 71, 782-799, doi:10.1175/JAS-D-13-0180.1, 2013.

Gao, Y.-X., Tang, M.-C., Luo, S.-W., Shen, Z.-B., and Li, C.: Some aspects of recent research on the Qinghai-Xizang Plateau Meteorology, B. Am. Meteorol. Soc., 62, 31-35, doi:10.1175/15200477(1981)062<0031:SAORRO>2.0.CO;2, 1981.

Garcia-Carreras, L., Parker, D. J., Taylor, C. M., Reeves, C. E., and Murphy, J. G.: Impact of mesoscale vegetation heterogeneities on the dynamical and thermodynamic properties of the planetary boundary layer, J. Geophys. Res., 115, D03102, doi:10.1029/2009JD012811, 2010.

Garcia-Carreras, L., Parker, D. J., and Marsham, J. H.: What is the mechanism for the modification of convective cloud distributions by land surface-induced flows?, J. Atmos. Sci., 68, 619-634, doi:10.1175/2010JAS3604.1, 2011.

Gerken, T., Babel, W., Hoffmann, A., Biermann, T., Herzog, M., Friend, A. D., Li, M., Ma, Y., Foken, T., and Graf, H.-F.: Turbulent flux modelling with a simple 2-layer soil model and extrapolated surface temperature applied at Nam Co Lake basin on the Tibetan Plateau, Hydrol. Earth Syst. Sci., 16, 1095-1110, doi:10.5194/hess-16-1095-2012, 2012.

Gerken, T., Babel, W., Sun, F., Herzog, M., Ma, Y., Foken, T., and Graf, H.-F.: Uncertainty in atmospheric profiles and the impact on modeled convection development at Nam Co Lake, Tibetan Plateau, J. Geophys. Res., 118, 12317-12331, doi:10.1002/2013JD020647, 2013a.

Gerken, T., Fuchs, K., and Babel, W.: Documentation of the Atmospheric Boundary Layer Experiment, Nam Tso, Tibet 8 July8 August 2012, Arbeitsergebnisse 53, University of Bayreuth, Bayreuth, 2013b.

Gerken, T., Biermann, T., Babel, W., Herzog, M., Ma, Y., Foken, T., and Graf, H.-F.: A modelling investigation into lakebreeze development and convection triggering in the Nam Co Lake basin, Tibetan Plateau, Theor. Appl. Climatol., 117, 149167, doi:10.1007/s00704-013-0987-9, 2014.

Gochis, D. J., Jimenez, A., Watts, C. J., Garatuza-Payan, J., and Shuttleworth, W. J.: Analysis of 2002 and 2003 warm-season precipitation from the North American Monsoon Experiment Event Rain Gauge Network, Mon. Weather Rev., 132, 29382953, doi:10.1175/MWR2838.1, 2004

Golaz, J.-C., Jiang, H., and Cotton, W. R.: A large-eddy simulation study of cumulus clouds over land and sensitivity to soil moisture, Atmos. Res., 59-60, 373-392, doi:10.1016/S01698095(01)00113-2, 2001.

Graf, H.-F., Herzog, M., Oberhuber, J. M., and Textor, C.: Effect of environmental conditions on volcanic plume rise, J. Geophys. Res., 104, 24309-24320, doi:10.1029/1999JD900498, 1999.

Guo, H., Penner, J., and Herzog, M.: Comparison of the vertical velocity used to calculate the cloud droplet number concentration in a cloud-resolving and a global climate model, in: Fourteenth ARM Science Team Meeting Proceedings, edited by: Carrothers, D., Department of Energy, Boston, 1-6, 2004.

Haginoya, S., Fujii, H., Kuwagata, T., Xu, J., Ishigooka, Y., Kang, S., and Zhang, Y.: Air-lake interaction features found in heat and water exchanges over Nam Co on the Tibetan Plateau, 
Scient. Onl. Lett. Atmos., 5, 172-175, doi:10.2151/sola.2009044, 2009.

Hauck, C., Barthlott, C., Krauss, L., and Kalthoff, N.: Soil moisture variability and its influence on convective precipitation over complex terrain, Q. J. Roy. Meteorol. Soc., 137, 42-56, doi:10.1002/qj.766, 2011.

Herzog, M., Graf, H.-F., Textor, C., and Oberhuber, J. M.: The effect of phase changes of water on the development of volcanic plumes, J. Volcanol. Geoth. Res., 87, 55-74, doi:10.1016/S03770273(98)00100-0, 1998.

Herzog, M., Oberhuber, J. M., and Graf, H.-F.: A prognostic turbulence scheme for the nonhydrostatic plume model ATHAM, J. Atmos. Sci., 60, 2783-2796, doi:10.1175/15200469(2003)060<2783:APTSFT>2.0.CO;2, 2003.

Hohenegger, C., Brockhaus, P., Bretherton, C. S., and Schär, C.: The soil moisture-precipitation feedback in simulations with explicit and parameterized convection, J. Climate, 22, 5003-5020, doi:10.1175/2009JCLI2604.1, 2009.

Immerzeel, W. W., van Beek, L. P. H., and Bierkens, M. F. P.: Climate change will affect the Asian water towers, Science, 328, 1382-1385, doi:10.1126/science.1183188, 2010.

Kang, S., Xu, Y., You, Q., Flügel, W.-A., Pepin, N., and Yao, T.: Review of climate and cryospheric change in the Tibetan Plateau, Environ. Res. Lett., 5, 015101, doi:10.1088/17489326/5/1/015101, 2010.

Kirshbaum, D. J.: Cloud-resolving simulations of deep convection over a heated mountain, J. Atmos. Sci., 68, 361-378, doi:10.1175/2010JAS3642.1, 2011.

Kirshbaum, D. J. and Durran, D. R.: Factors governing cellular convection in orographic precipitation, J. Atmos. Sci., 61, 682-698, doi:10.1175/1520-0469(2004)061<0682:FGCCIO>2.0.CO;2, 2004.

Kracher, D., Mengelkamp, H.-T., and Foken, T.: The residual of the energy balance closure and its influence on the results of three SVAT models, Meteorol. Z., 18, 647-661, doi:10.1127/09412948/2009/0412, 2009.

Kurita, N. and Yamada, H.: The role of local moisture recycling evaluated using stable isotope data from over the middle of the Tibetan Plateau during the monsoon season, J. Hydrometeorol., 9, 760-775, doi:10.1175/2007JHM945.1, 2008.

Kurosaki, Y. and Kimura, F.: Relationship between topography and daytime cloud activity around Tibetan Plateau, J. Meteorol. Soc. Jpn., 80, 1339-1355, 2002.

Kuwagata, T., Numaguti, A., and Endo, N.: Diurnal variation of water vapor over the central Tibetan Plateau during summer, J. Meteorol. Soc. Jpn., 79, 401-418, doi:10.2151/jmsj.79.401, 2001.

Langmann, B., Herzog, M., and Graf, H.-F.: Radiative forcing of climate by sulfate aerosols as determined by a regional circulation chemistry transport model, Atmos. Environ., 32, 2757-2768, doi:10.1016/S1352-2310(98)00028-4, 1998.

Li, M., Ma, Y., Hu, Z., Ishikawa, H., and Oku, Y.: Snow distribution over the Namco lake area of the Tibetan Plateau, Hydrol. Earth Syst. Sci., 13, 2023-2030, doi:10.5194/hess-13-20232009, 2009

Liang, X.-Z. and Wang, W.-C.: Associations between China monsoon rainfall and tropospheric jets, Q. J. Roy. Meteorol. Soc., 124, 2597-2623, doi:10.1002/qj.49712455204, 1998.

Liu, J., Kang, S., Gong, T., and Lu, A.: Growth of a high-elevation large inland lake, associated with climate change and permafrost degradation in Tibet, Hydrol. Earth Syst. Sci., 14, 481-489, doi:10.5194/hess-14-481-2010, 2010.

Ma, Y., Wang, Y., Wu, R., Hu, Z., Yang, K., Li, M., Ma, W., Zhong, L., Sun, F., Chen, X., Zhu, Z., Wang, S., and Ishikawa, H.: Recent advances on the study of atmosphere-land interaction observations on the Tibetan Plateau, Hydrol. Earth Syst. Sci., 13, 1103-1111, doi:10.5194/hess-13-1103-2009, 2009.

Mauder, M. and Foken, T.: Documentation and instruction manual of the eddy covariance software package TK2, Arbeitsergebnisse 26, University of Bayreuth, Bayreuth, 2004.

Mauder, M. and Foken, T.: Documentation and Instruction Manual of the Eddy-Covariance Software Package TK3, Arbeitsergebnisse 46, University of Bayreuth, Bayreuth, 2011.

Maussion, F., Scherer, D., Finkelnburg, R., Richters, J., Yang, W., and Yao, T.: WRF simulation of a precipitation event over the Tibetan Plateau, China - an assessment using remote sensing and ground observations, Hydrol. Earth Syst. Sci., 15, 1795-1817, doi:10.5194/hess-15-1795-2011, 2011.

Maussion, F., Scherer, D., Mölg, T., Collier, E., Curio, J., and Finkelnburg, R.: Precipitation seasonality and variability over the tibetan plateau as resolved by the High Asia Reanalysis, J. Climate, 27, 1910-1927, doi:10.1175/JCLI-D-13-00282.1, 2014.

Mlawer, E. J., Taubman, S. J., Brown, P. D., Iacono, M. J., and Clough, S. A.: Radiative transfer for inhomogeneous atmospheres: RRTM, a validated correlated-k model for the longwave, J. Geophys. Res., 102, 16663-16682, doi:10.1029/97JD00237, 1997.

Molnar, P., Boos, W. R., and Battisti, D. S.: Orographic controls on climate and paleoclimate of Asia: thermal and mechanical roles for the Tibetan Plateau, Annu. Rev. Earth Pl. Sc., 38, 77-102, doi:10.1146/annurev-earth-040809-152456, 2010.

Mügler, I., Gleixner, G., Günther, F., Mäusbacher, R., Daut, G., Schütt, B., Berking, J., Schwalb, A., Schwark, L., Xu, B., Yao, T., Zhu, L., and Yi, C.: A multi-proxy approach to reconstruct hydrological changes and Holocene climate development of Nam Co, Central Tibet, J. Paleolimnol., 43, 625-648, doi:10.1007/s10933009-9357-0, 2010.

$\mathrm{Ni}$, J.: Impacts of climate change on Chinese ecosystems: key vulnerable regions and potential thresholds, Reg. Environ. Change, 11, 49-64, doi:10.1007/s10113-010-0170-0, 2011.

Oberhuber, J. M., Herzog, M., Graf, H.-F., and Schwanke, K.: Volcanic plume simulation on large scales, J. Volcanol. Geoth. Res., 87, 29-53, doi:10.1016/S0377-0273(98)00099-7, 1998.

Pal, J. S. and Eltahir, E. A. B.: Pathways relating soil moisture conditions to future summer rainfall within a model of the land-atmosphere system, J. Climate, 14, 1227-1242, doi:10.1175/1520-0442(2001)014<1227:PRSMCT>2.0.CO;2, 2001.

Pan, Z., Takle, E., Segal, M., and Turner, R.: Influences of model parameterization schemes on the response of rainfall to soil moisture in the central United States, Mon. Weather Rev., 124, 1786-1802, doi:10.1175/15200493(1996)124<1786:IOMPSO>2.0.CO;2, 1996.

Patton, E. G., Sullivan, P. P., and Moeng, C.-H.: The influence of idealized heterogeneity on wet and dry planetary boundary layers coupled to the land surface, J. Atmos. Sci., 62, 2078-2097, doi:10.1175/JAS3465.1, 2005.

Petch, J. C., Blossey, P. N., and Bretherton, C. S.: Differences in the lower troposphere in two- and three-dimensional cloud-resolving 
model simulations of deep convection, Q. J. Roy. Meteorol. Soc., 134, 1941-1946, doi:10.1002/qj.315, 2008.

Rebmann, C., Kolle, O., Heinesch, B., Queck, R., Ibrom, A., and Aubinet, M.: Data acquisition and flux calculations, in: Eddy Covariance, edited by: Aubinet, M., Vesala, T., and Papale, D., Springer Atmospheric Sciences, Springer, Dordrecht, 59-83, doi:10.1007/978-94-007-2351-1_3, 2012.

Seneviratne, S. I., Corti, T., Davin, E. L., Hirschi, M., Jaeger, E. B., Lehner, I., Orlowsky, B., and Teuling, A. J.: Investigating soil moisture-climate interactions in a changing climate: a review, Earth-Sci. Rev., 99, 125-161, doi:10.1016/j.earscirev.2010.02.004, 2010.

Shen, M., Zhang, G., Cong, N., Wang, S., Kong, W., and Piao, S.: Increasing altitudinal gradient of spring vegetation phenology during the last decade on the QinghaiTibetan Plateau, Agr. Forest Meteorol., 189-190, 71-80, doi:10.1016/j.agrformet.2014.01.003, 2014.

Taniguchi, K. and Koike, T.: Seasonal variation of cloud activity and atmospheric profiles over the eastern part of the Tibetan Plateau, J. Geophys. Res., 113, D10104, doi:10.1029/2007JD009321, 2008.

Taylor, C. M., Parker, D. J., and Harris, P. P.: An observational case study of mesoscale atmospheric circulations induced by soil moisture, Geophys. Res. Lett., 34, L15801, doi:10.1029/2007GL030572, 2007.

Taylor, C. M., de Jeu, R. A. M., Guichard, F., Harris, P. P., and Dorigo, W. A.: Afternoon rain more likely over drier soils, Nature, 489, 423-426, doi:10.1038/nature11377, 2012.

Tian, L., Masson-Delmotte, V., Stievenard, M., Yao, T., and Jouzel, J.: Tibetan Plateau summer monsoon northward extent revealed by measurements of water stable isotopes, J. Geophys. Res., 106, 28081-28088, doi:10.1029/2001JD900186, 2001.

Tian, L., Yao, T., Schuster, P. F., White, J. W. C., Ichiyanagi, K., Pendall, E., Pu, J., and Yu, W.: Oxygen-18 concentrations in recent precipitation and ice cores on the Tibetan Plateau, J. Geophys. Res., 108, D094293, doi:10.1029/2002JD002173, 2003.

Tian, L., Yao, T., MacClune, K., White, J. W. C., Schilla, A., Vaughn, B., Vachon, R., and Ichiyanagi, K.: Stable isotopic variations in west China: a consideration of moisture sources, J. Geophys. Res., 112, D10112, doi:10.1029/2006JD007718, 2007.

Trentmann, J., Luderer, G., Winterrath, T., Fromm, M. D., Servranckx, R., Textor, C., Herzog, M., Graf, H.-F., and Andreae, M. O.: Modeling of biomass smoke injection into the lower stratosphere by a large forest fire (Part I): reference simulation, Atmos. Chem. Phys., 6, 5247-5260, doi:10.5194/acp-65247-2006, 2006.

Twine, T. E., Kustas, W. P., Norman, J. M., Cook, D. R., Houser, P. R., Meyers, T. P., Prueger, J. H., Starks, P. J., and Wesely, M. L.: Correcting eddy-covariance flux underestimates over a grassland, Agr. Forest Meteorol., 103, 279-300, doi:10.1016/S0168-1923(00)00123-4, 2000.

Ueno, K.: Characteristics of plateau-scale precipitation in Tibet estimated by satellite data during 1993 monsoon season, J. Meteorol. Soc. Jpn., 76, 533-548, 1998.

Ueno, K., Takano, S., and Kusaka, H.: Nighttime precipitation induced by a synoptic-scale convergence in the central Tibetan Plateau, J. Meteorol. Soc. Jpn., 87A, 459-472, doi:10.2151/jmsj.87.459, 2009.
Uyeda, H., Yamada, H., Horikomi, J., Shirooka, R., Shimizu, S., Liping, L., Ueno, K., Fujii, H., and Koike, T.: Characteristics of convective clouds observed by a doppler radar at Naqu on Tibetan Plateau during the GAME-Tibet IOP, J. Meteorol. Soc. Jpn., 79, 463-474, doi:10.2151/jmsj.79.463, 2001.

Wang, J., Zhu, L., Daut, G., Ju, J., Lin, X., Wang, Y., and Zhen, X.: Investigation of bathymetry and water quality of Lake Nam Co, the largest lake on the central Tibetan Plateau, China, Limnology, 10, 149-158, doi:10.1007/s10201-009-0266-8, 2009.

Wu, C.-M., Stevens, B., and Arakawa, A.: What controls the transition from shallow to deep convection?, J. Atmos. Sci., 66, 17931806, doi:10.1175/2008JAS2945.1, 2009.

Yamada, H.: Numerical simulations of the role of land surface conditions in the evolution and structure of summertime thunderstorms over a flat highland, Mon. Weather Rev., 136, 173-188, doi:10.1175/2007MWR2053.1, 2008.

Yamada, H. and Uyeda, H.: Transition of the rainfall characteristics related to the moistening of the land surface over the central Tibetan Plateau during the Summer of 1998, Mon. Weather Rev., 134, 3230-3247, doi:10.1175/MWR3235.1, 2006.

Yanai, M., Li, C., and Song, Z.: Seasonal heating of the Tibetan Plateau and its effects on the evolution of the Asian summer monsoon, J. Meteorol. Soc. Jpn., 70, 319-351, 1992.

Yang, K., Koike, T., Fujii, H., Tamura, T., Xu, X., Bian, L., and Zhou, M.: The daytime evolution of the atmospheric boundary layer and convection over the Tibetan Plateau: observations and simulations, J. Meteorol. Soc. Jpn., 82, 1777-1792, doi:10.2151/jmsj.82.1777, 2004.

Yang, K., Ye, B., Zhou, D., Wu, B., Foken, T., Qin, J., and Zhou, Z.: Response of hydrological cycle to recent climate changes in the Tibetan Plateau, Climatic Change, 109, 517-534, doi:10.1007/s10584-011-0099-4, 2011.

Yang, K., Wu, H., Qin, J., Lin, C., Tang, W., and Chen, Y.: Recent climate changes over the Tibetan Plateau and their impacts on energy and water cycle: a review, Global Planet. Change, 112, 79-91, doi:10.1016/j.gloplacha.2013.12.001, 2014.

Yao, T., Pu, J., Lu, A., Wang, Y., and Yu, W.: Recent glacial retreat and its impact on hydrological processes on the Tibetan Plateau, China, and surrounding regions, Arct. Antarct. Alp. Res., 39, 642-650, doi:10.1657/1523-0430(07-510)[YAO]2.0.CO;2, 2007.

Yatagai, A.: Estimation of precipitable water and relative humidity over the Tibetan Plateau from GMS-5 water vapor channel data, J. Meteorol. Soc. Jpn., 79, 589-598, doi:10.2151/jmsj.79.589, 2001.

Zhang, D., Xu, W., Li, J., Cai, Z., and An, D.: Frost-free season lengthening and its potential cause in the Tibetan Plateau from 1960 to 2010, Theor. Appl. Climatol., 115, 441-450, doi:10.1007/s00704-013-0898-9, 2014.

Zhou, Y., Gao, S., and Shen, S. S. P.: A Diagnostic study of formation and structures of the meiyu front system over east Asia, J. Meteorol. Soc. Jpn., 82, 1565-1576, doi:10.2151/jmsj.82.1565, 2004. 